\title{
NEUROENDOCRINE AND METABOLIC EFFECTS OF GENERAL ANAESTHESIA DURING SPONTANEOUS BREATHING, CONTROLLED BREATHING, MILD HYPOXIA, AND MILD HYPERCARBIA*
}

\author{
Allen B. Dobkin, M.D., Peter H. Byles, M.B., and John F. Neville, Jr., M.D.
}

Vision is as necessary an element in scientific achievement as is the carefully controlled experiment.

-Ernest Gellhorn, 1953

SOME OF THE NEUROENDOCRINE sUBSTANCES that play a prominent role in the central nervous system are found in the peripheral circulation. Their exact functions are not entirely clear, but it appears evident that alterations in their concentration in the circulating blood are associated with profound overt mental and physical changes, ${ }^{1-4}$ as well as possibly initiating sudden serious disturbances of pulmonary ventilation, myocardial contractility, microcirculatory homeostasis, gastrointestinal and renal function, and carbohydrate metabolism. ${ }^{5-\theta}$ These in turn may lead to the development of a shock-like state and death.

The purpose of this study was to make a precise systematic inquiry into the effects of general anaesthetics as administered in clinical practice on the circulating blood level of four biogenic amines and to attempt to interrelate these with any changes that might appear in the mean arterial blood pressure, urine output, haematocrit, blood water, blood sugar, serum potassium, serum inorganic phosphorus, pyruvate, lactate, oxygen tension, acid-base balance, and serum transaminases (SGOT and SGPT).

\section{Materials ANd Methods}

Serial crossover tests were carried out in four consecutive sets of experiments in 10 to 15 trained, large (20 to $30 \mathrm{~kg}$.) male dogs. Each animal received a general anaesthetic at one- to two-week intervals without prior administration of premedicant drugs or antisialogogues. After an overnight fast, a dog was weighed, then an intravenous infusion of 0.9 per cent saline was started in a forepaw vein after drawing a blood sample for estimation of blood sugar, serum potassium, serum inorganic phosphorus, SGOT, SGPT, whole blood histamine, and serotonin and plasma catecholamines (epinephrine and norepinephrine). Anaesthesia was then induced with $20 \mathrm{mg}$. $/ \mathrm{kg}$. thiopental (2.5\% solution), and the dog was intubated with a large cuffed tube that was attached to a gas machine which delivered $\mathrm{N}_{2} \mathrm{O}+\mathrm{O}_{2}$ (except with cyclopropane, when $\mathrm{N}_{2} \mathrm{O}$ was not used). A gas flow was used sufficient to provide a minute ventilation of 350 to $400 \mathrm{ml} . / \mathrm{kg}$.

\footnotetext{
-From the Anesthesiology Laboratory, State University of New York, Upstate Medical Center, Syracuse, New York, U.S.A. Supported by grants-in-aid from Abbott Laboratories, Ayerst Laboratories, McNeil Laboratories, E. R. Squibb \& Son, and U.S.P.H.S. grant 05402-04, 5. Presented at the Annual Meeting of the Canadian Anaesthetists' Society in Charlottetown, Prince Edward Island, June 24, 1965.
} 
(checked with a Wright Respirometer). An E.C.G. (lead 2) was attached, and a urinary catheter was inserted into the bladder for drainage. Gravity collection of urine was arranged using a calibrated trap bottle. A 19-gauge needle was inserted into the femoral artery and attached to a damped aneroid manometer for measurement of mean arterial blood pressure. When the above arrangements were completed, an arterial blood sample was drawn anaerobically for measurement of $\mathrm{pH}, P_{\mathrm{aco}_{2}}, P_{\mathrm{aO}_{2}}$ and haematocrit, and free-flowing arterial blood was collected for measurement of whole blood lactate, pyruvate, and blood-water content. The infusion saline was given in an amount sufficient to replace the blood volume removed for the laboratory tests, except with thiopental and Innovar anaesthesia in which tests an additional 100 to $150 \mathrm{ml}$. was administered.

During the experiments, the dogs were maintained under moderately deep anaesthesia for 90 minutes with the anaesthetics shown in Table I. Under the

TABLE I

Agents Used for Maintenance of Deep Anaesthesia for 90 Minutes Following INDUCTION WITH $20 \mathrm{mg} . / \mathrm{kg}$. ThIOPENTAL

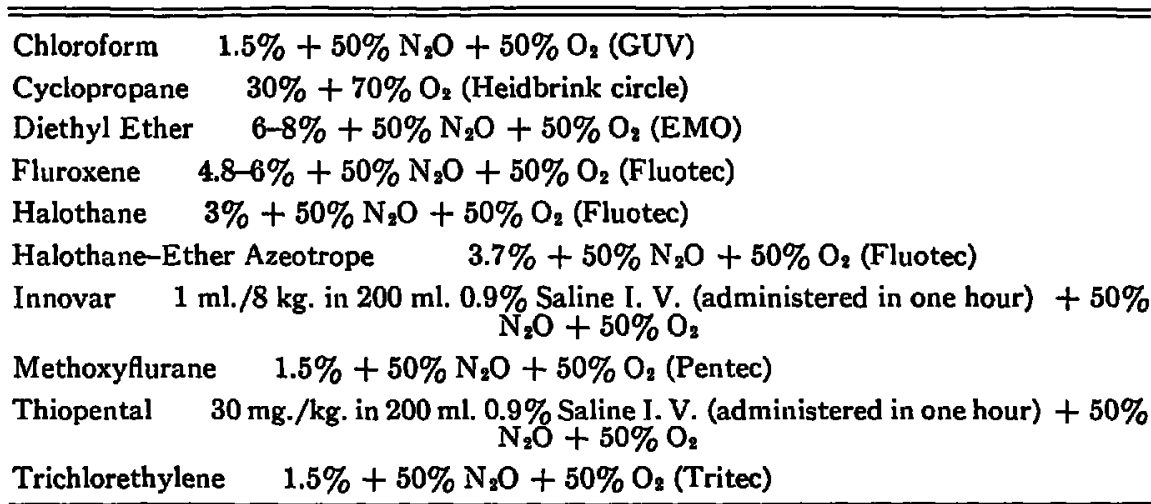

first condition (106 experiments), the animals were allowed to breathe spontaneously except with chloroform, cyclopropane, and Innovar, with which respiration was assisted or controlled as required (if it was apparent that a dog was becoming virtually apnoeic). In the remaining three conditions, pulmonary ventilation was controlled by a respirator with a minute volume of 350 to $400 \mathrm{ml} / \mathrm{kg}$., using 50 per cent $\mathrm{N}_{2} \mathrm{O}+50$ per cent $\mathrm{O}_{2}$ (127 experiments); 85 per cent $\mathrm{N}_{2} \mathrm{O}+15$ per cent $\mathrm{O}_{2}$ (mild hypoxia-136 experiments) and 50 per cent $\mathrm{N}_{2} \mathrm{O}+47.5$ per cent $\mathrm{O}_{2}+2.5$ per cent $\mathrm{CO}_{2}$ (mild hypercarbia-95 experiments) respectively.

At the end of the 90 minutes of anaesthesia, arterial and venous blood samples were drawn again for the analyses noted above. Anaesthetics were then discontinued and the dog was ventilated with 100 per cent oxygen until it recovered consciousness. The animal was then kept under direct surveillance until it was able to ambulate. During each experiment, recordings of the E.C.G., the reading of mean arterial blood pressure, and the volume of urinary drainage were taken every 10 minutes. Notes were kept of clinical events during anaesthesia and recovery. 
Between experiments the dogs were cared for in "dog runs" and in cages where they received a routine diet with meat (high protein) supplements. A few of the animals developed urinary infection from repeated catheterization and were treated with appropriate antibiotics. On occasion, a parenteral infusion of five per cent dextrose in water was administered for a day or two following a test if an animal did not take food or did not recover completely from a test.

\section{Laboratory Procedures}

Arterial blood samples were analyzed for $\mathrm{pH}, P_{\mathrm{aco}}$, and $P_{\mathrm{aO}_{2}}$ on an Epsco Medical Blood Parameter Analyzer using a constant temperature bath (37 ${ }^{\circ} \mathrm{C}$.), a Metrohm pH electrode, Clark electrode for $P_{\mathrm{aO}}$ and Severinghaus $P_{\mathrm{acO}}$ electrode. ${ }^{10}$ Oxygen saturation was derived from the Rahn and Fenn chart, using the direct measurements of $P_{\mathrm{acO}_{2}}$ and $P_{\mathrm{nO}_{2}}{ }^{11}$ Plasma bicarbonate was derived from a line chart based upon the Henderson-Hasselbach equation. Haematocrit was measured by the Natelson micromethod. ${ }^{12}$ Duplicate enzymatic analyses of pyruvic and lactic acids in whole arterial blood were carried out by a modification of the spectrophotometric methods of Bücher (1963) and Hohorst (1963) respectively and expressed as $\mathrm{mM} / \mathrm{L}$. of blood water.13,14 Whole blood water was determined by weighing the arterial blood sample before and after drying in an oven and cooling in a desiccator. SGOT and SGPT were measured by the colorimetric method of Reitman and Frankel (1957)..$^{15}$ Blood sugar and serum inorganic phosphorus were measured on an auto-analyser using methods of Hoffman (1937) and of Fiske and Subbarow (1925) respectively. ${ }^{16,17}$ Serum potassium was measured on a flame photometer. Duplicate whole blood histamine and serotonin estimations were made by the method of Noah and Brand (1963) adapted to the Turner fluorometer. ${ }^{18-20}$ Duplicate assays of plasma catecholamines were made fluorometrically by modification of the trihydroxindole methods of Cohen and Goldenberg (1957) and Price and Price (1957). ${ }^{21,22}$

Laboratory estimations were analysed statistically for at least ten experiments with each anaesthetic administered under each of the four conditions described above.

\section{RESULTS*}

During the experiments there was a moderate to marked reduction $(>10 \%)$ in the mean arterial blood pressure with Innovar, halothane, halothane-ether azeotrope, and methoxyflurane. Cyclopropane, diethyl ether, thiopental and fluroxene usually caused a slight or moderate elevation of the mean arterial blood pressure, whereas the changes with trichlorethylene and chloroform were variable, but without excessive elevation or depression. Mean heart rate increased appreciably with diethyl ether $(\sim 20 \%)$ and slightly $(<5 \%)$ with thiopental and fluroxene. There was a marked decrease in the mean heart rate with Innovar ( $\sim 50 \%)$, cyclopropane ( $\sim 30 \%$ ), halothane ( $20 \%)$, halothane-ether azeotrope $(\sim 15 \%)$, and methoxyflurane $(\sim 20 \%)$, and a slight decrease $(<5 \%)$ with chloroform and trichlorethylene (see Table II).

A variety of persistent ventricular arrhythmias appeared in most of the experi-

-Tabular data not shown were deleted to conserve space and will be furnished on request. 
TABLE II

Summary of Changes in Heart Rate and Mean Arterial Blood Pressure Due to General ANAESTHESIA

\begin{tabular}{|c|c|c|c|c|c|}
\hline & \multirow{2}{*}{$\begin{array}{l}\text { Number of } \\
\text { experiments }\end{array}$} & \multicolumn{2}{|c|}{ Heart rate/min. } & \multicolumn{2}{|c|}{$\begin{array}{l}\text { Mean arterial } \\
\text { blood pressure }(\mathrm{mm} \text {. } \mathrm{Hg} \text { ) }\end{array}$} \\
\hline & & start & end & start & end \\
\hline Thiopental & 50 & 157 & 161 & 134 & 156 \\
\hline Innovar & 54 & 163 & 84 & 131 & 95 \\
\hline Diethyl Ether & 48 & 159 & 189 & 130 & 142 \\
\hline Cyclopropane & 22 & 152 & 114 & 127 & 137 \\
\hline Chloroform & 47 & 157 & 154 & 135 & 140 \\
\hline Trichlorethylene & 47 & 157 & 150 & 138 & 130 \\
\hline Fluroxene & 47 & 162 & 166 & 137 & 143 \\
\hline Halothane & 47 & 165 & 138 & 138 & 121 \\
\hline Halothane-Ether Azeotrope & 47 & 162 & 143 & 143 & 130 \\
\hline Methoxyflurane & 48 & 158 & 134 & 131 & 90 \\
\hline
\end{tabular}

ments when the dogs were allowed to breathe spontaneously except with diethyl ether and thiopental. During the remaining experiments, in which pulmonary ventilation was controlled, ventricular arrhythmias only occurred occasionally and were evanescent. Except when thiopental was used throughout, a marked suppression of urine excretion occurred during virtually every experiment, which became apparent usually after 10 to 20 minutes of anaesthesia. SGOT and SGPT estimations were within normal limits in all of the experiments.

Spontaneous Respiration (106 Experiments)

The data are summarized in Table III and Figures 1, 2, and 3.

All the dogs had a slight respiratory acidosis following induction of anaesthesia with thiopental. During the maintenance period of anaesthesia the $\mathrm{pH}$ decreased appreciably following the addition of thiopental, diethyl ether, cyclopropane, chloroform, halothane-ether azeotrope and methoxyflurane; $P_{\mathrm{acO}}$ rose further, except with Innovar, diethyl ether, trichlorethylene, fluroxene, and halothane; plasma bicarbonate decreased appreciably with diethyl ether only; haematocrit rose significantly with diethyl ether, chloroform, and trichlorethylene; blood sugar rose significantly ( $>20 \%$ ) with Innovar, diethyl ether, and chloroform; serum potassium fell slightly with all agents (5 to 19\%); serum inorganic phosphorus rose with all agents ( 7 to $57 \%$ ); whole blood lactate and pyruvate rose with all agents except halothane; diethyl ether and fluroxene caused a striking rise. $\mathrm{L} / \mathrm{P}$ ratio was increased appreciably by diethyl ether only (114\%) and excess lactate was slight with thiopental and fluroxene and marked ( $>2 \mathrm{mM} / \mathrm{L}$.) with diethyl ether. Histamine increased during diethyl ether anaesthesia only (47\%); serotonin was increased ( $>25 \%$ ) by Innovar, chloroform, and fluroxene; epinephrine rose ( $>50 \%$ ) with thiopental and diethyl ether; norepinephrine rose (>50\%) with thiopental and diethyl ether, and total catecholamines increased ( $>25 \%$ ) with thiopental and diethyl ether only. Whole blood water decreased appreciably with diethyl ether and trichlorethylene. 


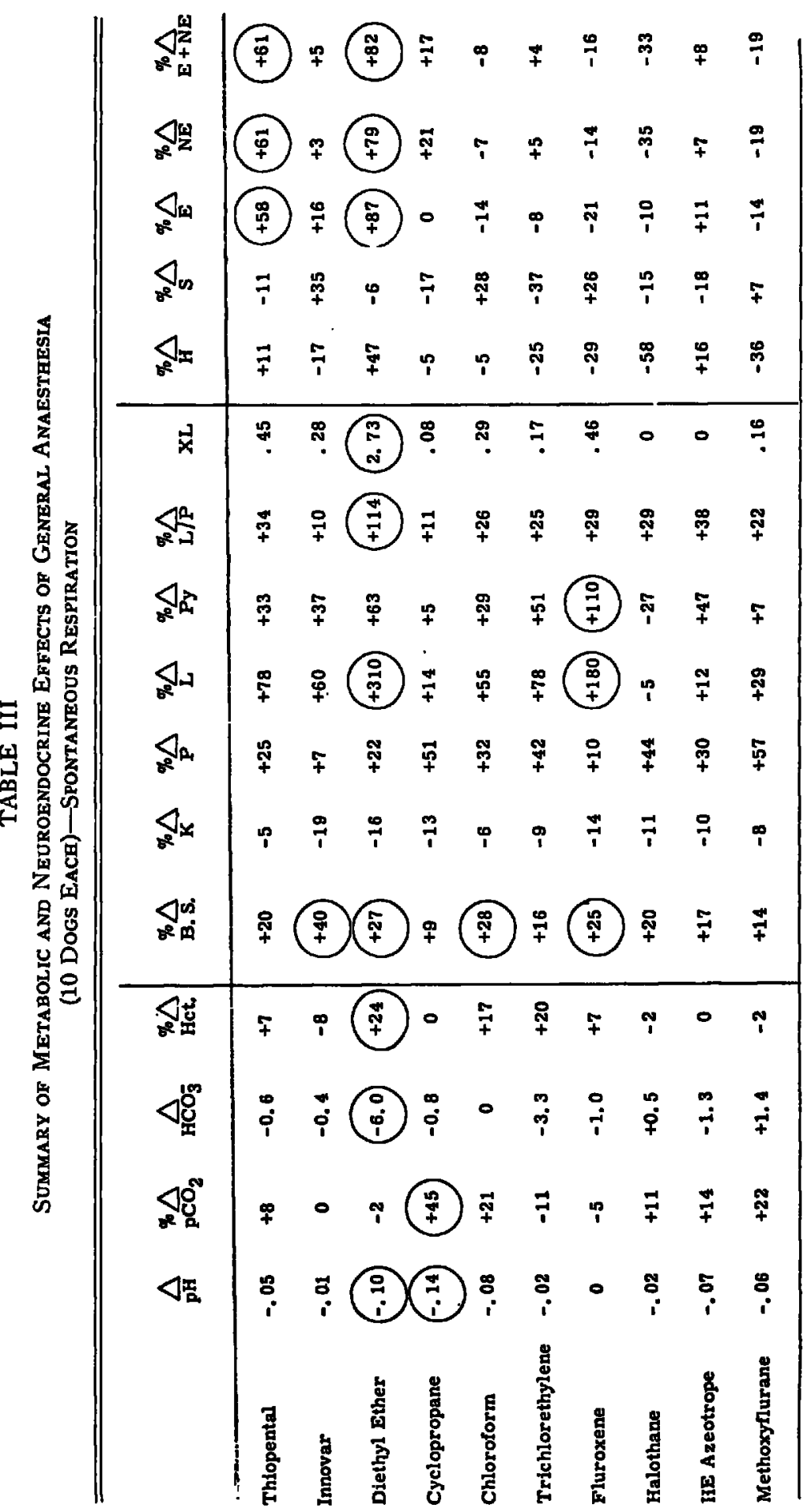



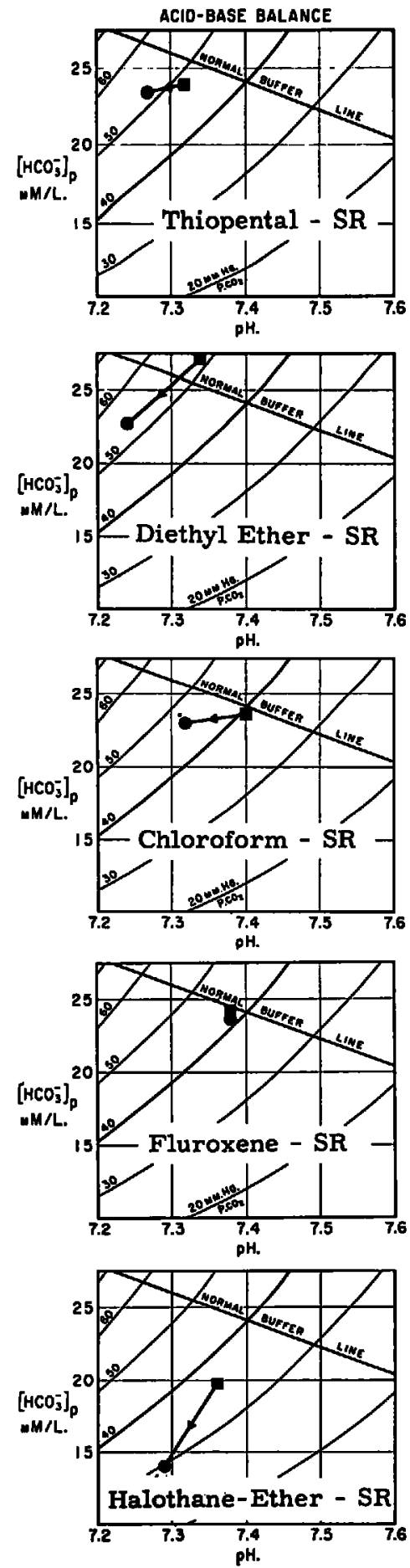
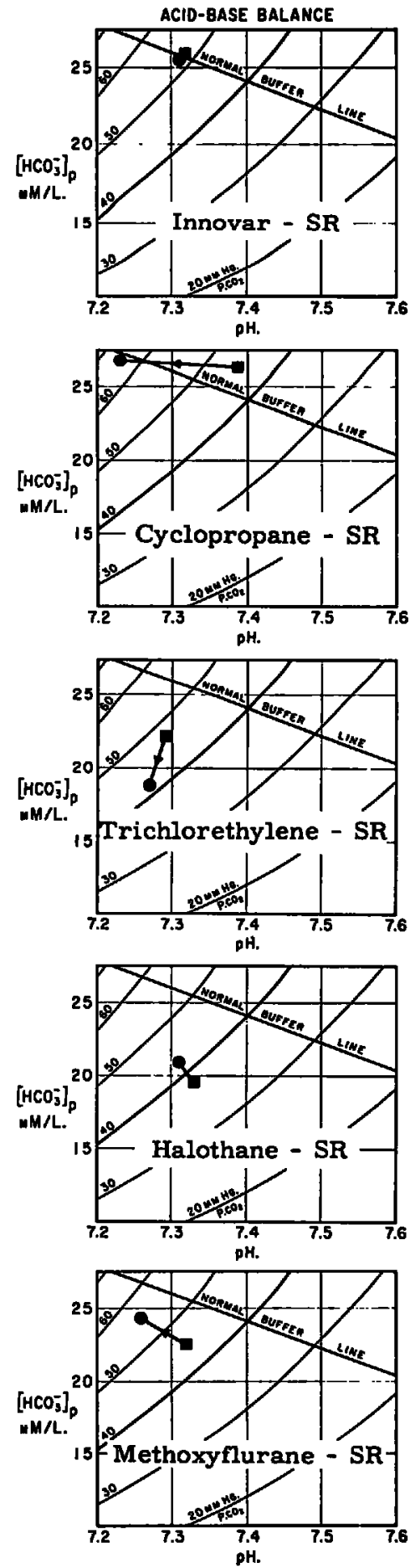

FIGURe 1. Acid-base balance-spontaneous respiration. 

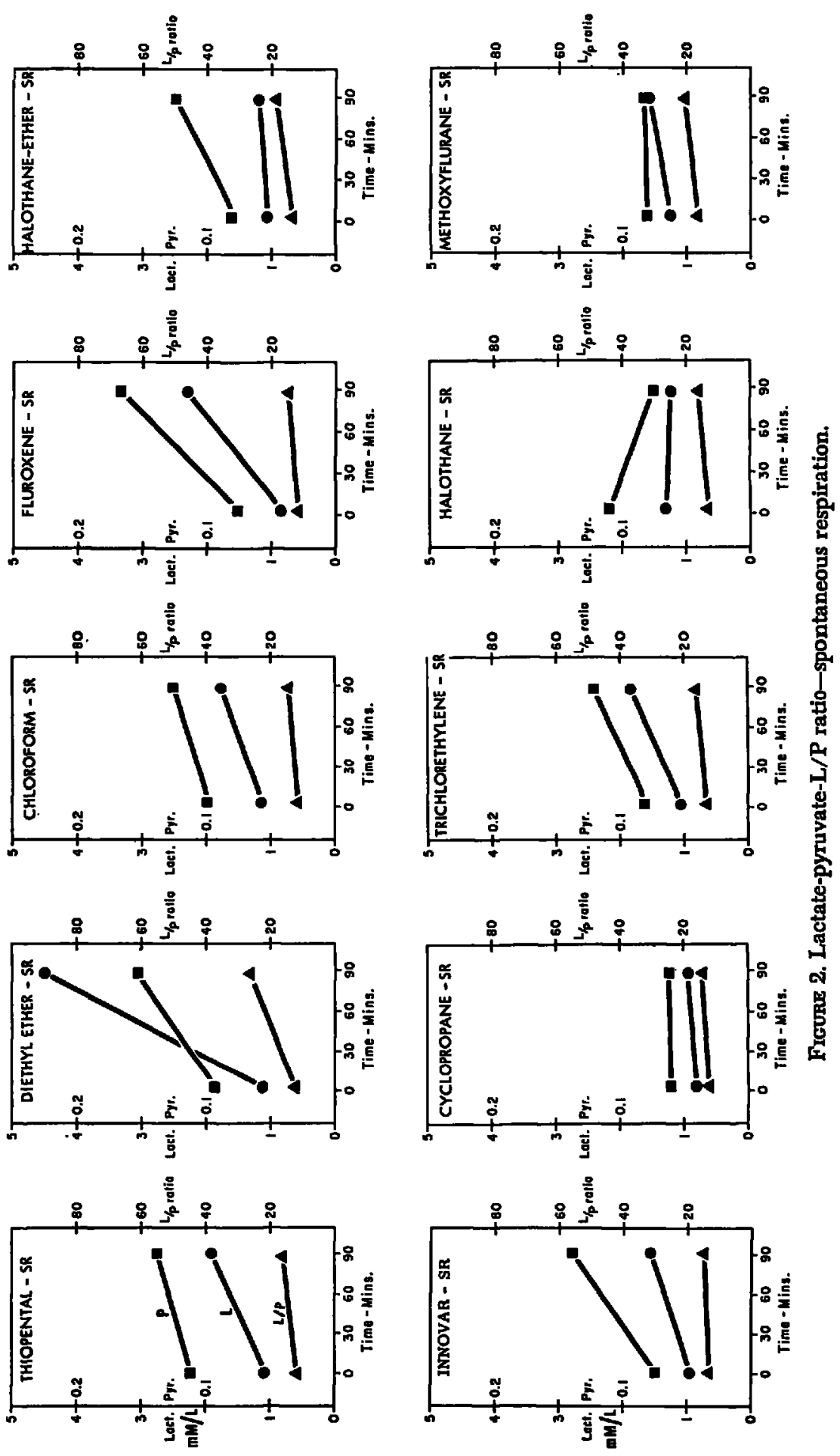

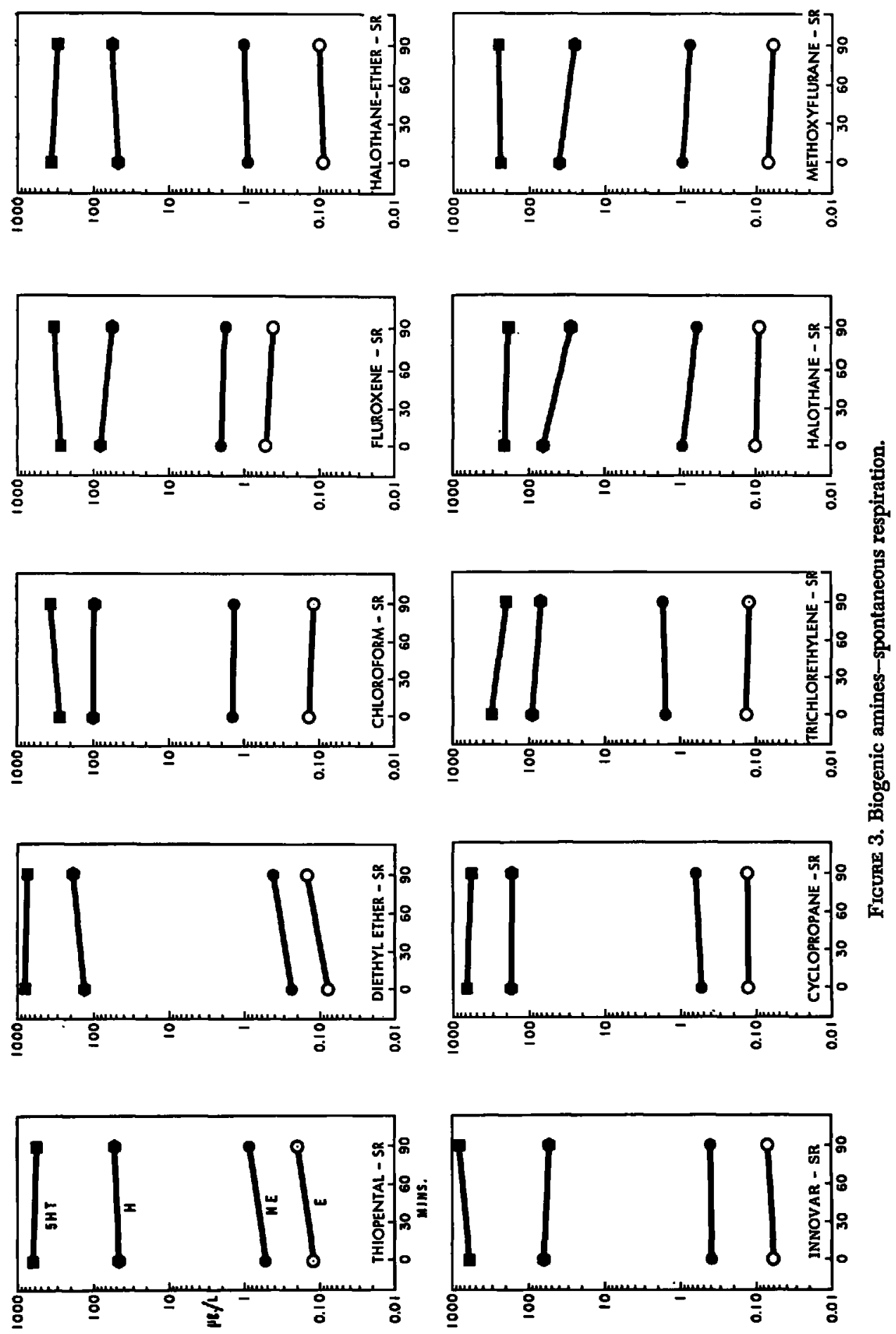
To summarize: Induction of anaesthesia with thiopental caused a mild respiratory acidosis. Spontaneous breathing during relatively deep general anaesthesia augmented the respiratory acidosis with thiopental, cyclopropane, chloroform, halothane-ether azeotrope and methoxyflurane. Innovar (briefly) and chloroform (consistently) caused periods of apnoea in dogs if breathing was not augmented artificially. Diethyl ether produced the most striking metabolic changes: acidosis, hyperglycaemia, haemoconcentration, and lactic and pyruvic acid accumulation with marked rise in $\mathrm{L} / \mathrm{P}$ ratio and excess lactate. Diethyl ether and thiopental increased circulating plasma catecholamines; whole blood histamine increased with ether, and serotonin increased during Innovar anaesthesia.

\section{Controlled Respiration (127 Experiments)}

The data are summarized in Table IV and Figures 4, 5, and 6.

A mild respiratory alkalosis (mean control $\mathrm{pH} 7.46$; mean control $P_{\mathrm{acO}} 27$ ) was produced following induction of anaesthesia with thiopental by mechanically controlling each dog's minute pulmonary ventilation at 350 to $400 \mathrm{ml} . / \mathrm{kg}$. During maintenance of anaesthesia the following changes occurred: $\mathrm{pH}$ decreased with diethyl ether only; $P_{\mathrm{aco}}$ remained consistently reduced in these tests; plasma bicarbonate was reduced by diethyl ether only; haematocrit rose significantly with diethyl ether only; blood sugar rose $(>20 \%)$ with Innovar, diethyl ether, cyclopropane, and chloroform, serum potassium decreased in all tests (9 to 23\%), serum inorganic phosphorus rose during diethyl ether (30\%) and cyclopropare (18\%) anaesthesia only. Whole blood lactate rose with all agents, especially with diethyl ether and fluroxene, while whole blood pyruvate rose with all agents except thiopental. L/P ratio increased strikingly with diethyl ether only (152\%), while excess lactate occurred appreciably with diethyl ether and fluroxene. Histamine levels did not increase appreciably with any anaesthetic; serotonin levels rose slightly with diethyl ether, fluroxene, and halothane, but the variation among individuals was great. Epinephrine increased appreciably with thiopental, Innovar, chloroform, cyclopropane, and trichlorethylene $(>25 \%)$; norepinephrine increased slightly (18 to $34 \%$ ) with all anaesthetics except chloroform and methoxyflurane, and total catecholamines increased appreciably with thiopental, diethyl ether, cyclopropane, and trichlorethylene. Blood water decreased ( $>3 \%$ ) with diethyl ether only.

To summarize: The metabolic changes were less obvious during controlled respiration; however, diethyl ether caused metabolic changes during controlled respiration that were similar to those with spontaneous respiration except for the rise in histamine and catecholamines. Thiopental consistently increased epinephrine levels appreciably. Cyclopropane increased epinephrine less with spontaneous breathing than with controlled breathing, probably owing to the deeper anaesthesia produced by intermittent positive pressure.

\section{Mild Hypoxia (with Controlled Respiration; 136 Experiments)}

Data are summarized in Table $V$ and Figures 7, 8, and 9.

All the dogs had a mild hypoxia after induction of anaesthesia with thiopental since their breathing was controlled with 15 per cent oxygen and 85 per cent nitrous oxide (mean control: $\mathrm{pH} 7.45 ; P_{\mathrm{acO}} \sim 28 ; P_{\mathrm{aO}_{2}}<75 \mathrm{~mm}$.). 


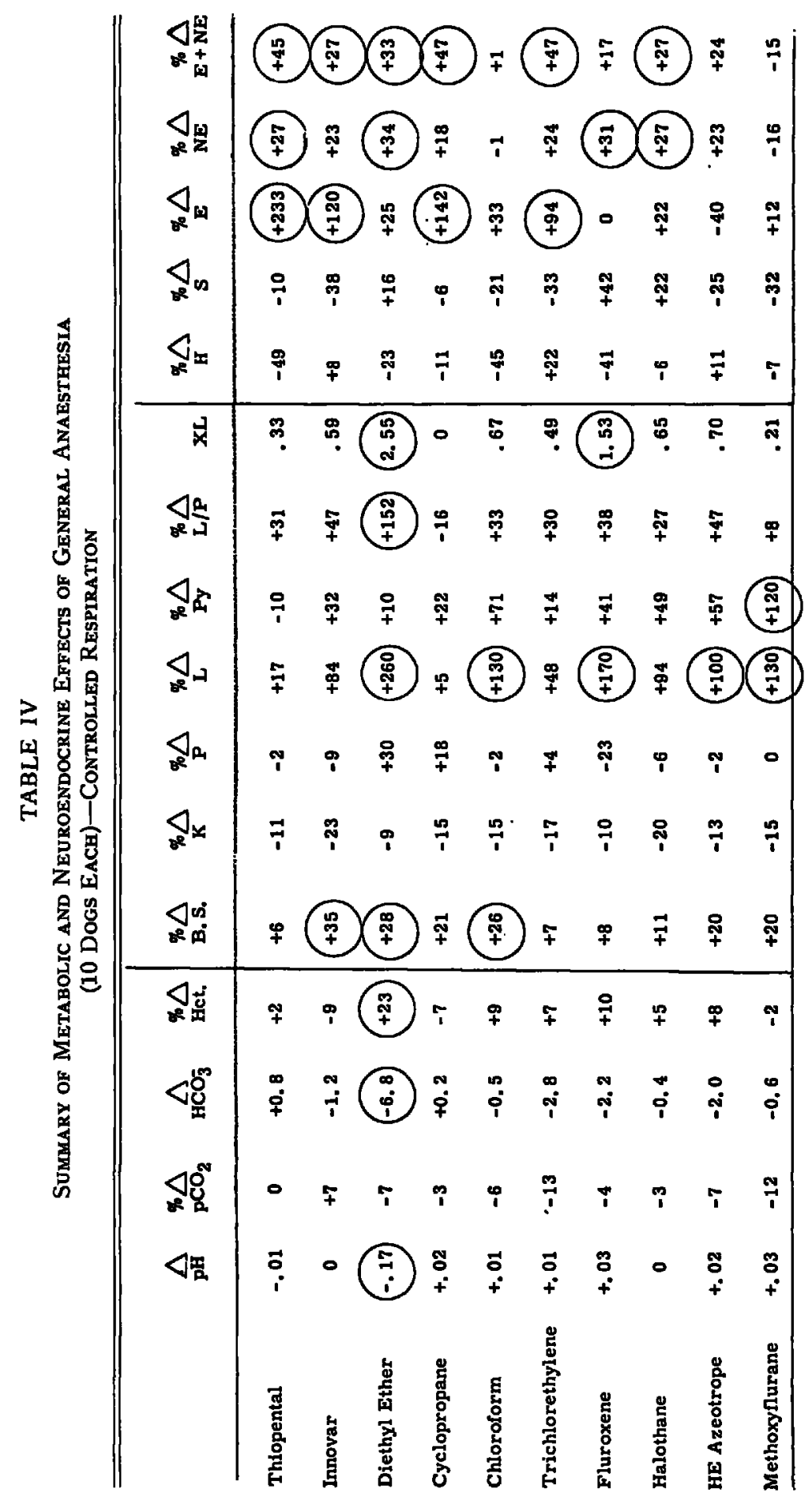



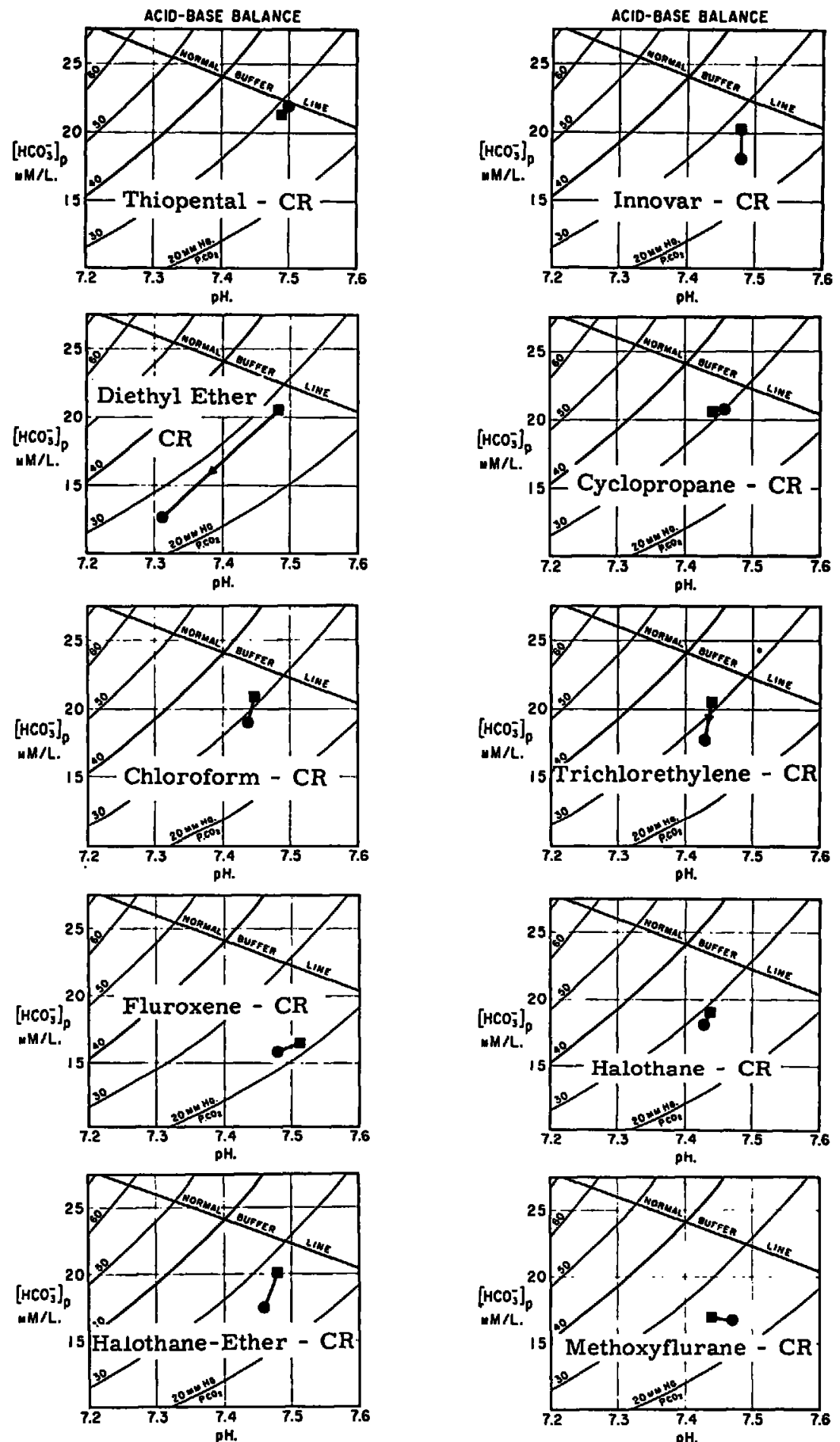

Figure 4. Acid-base balance-controlled respiration. 

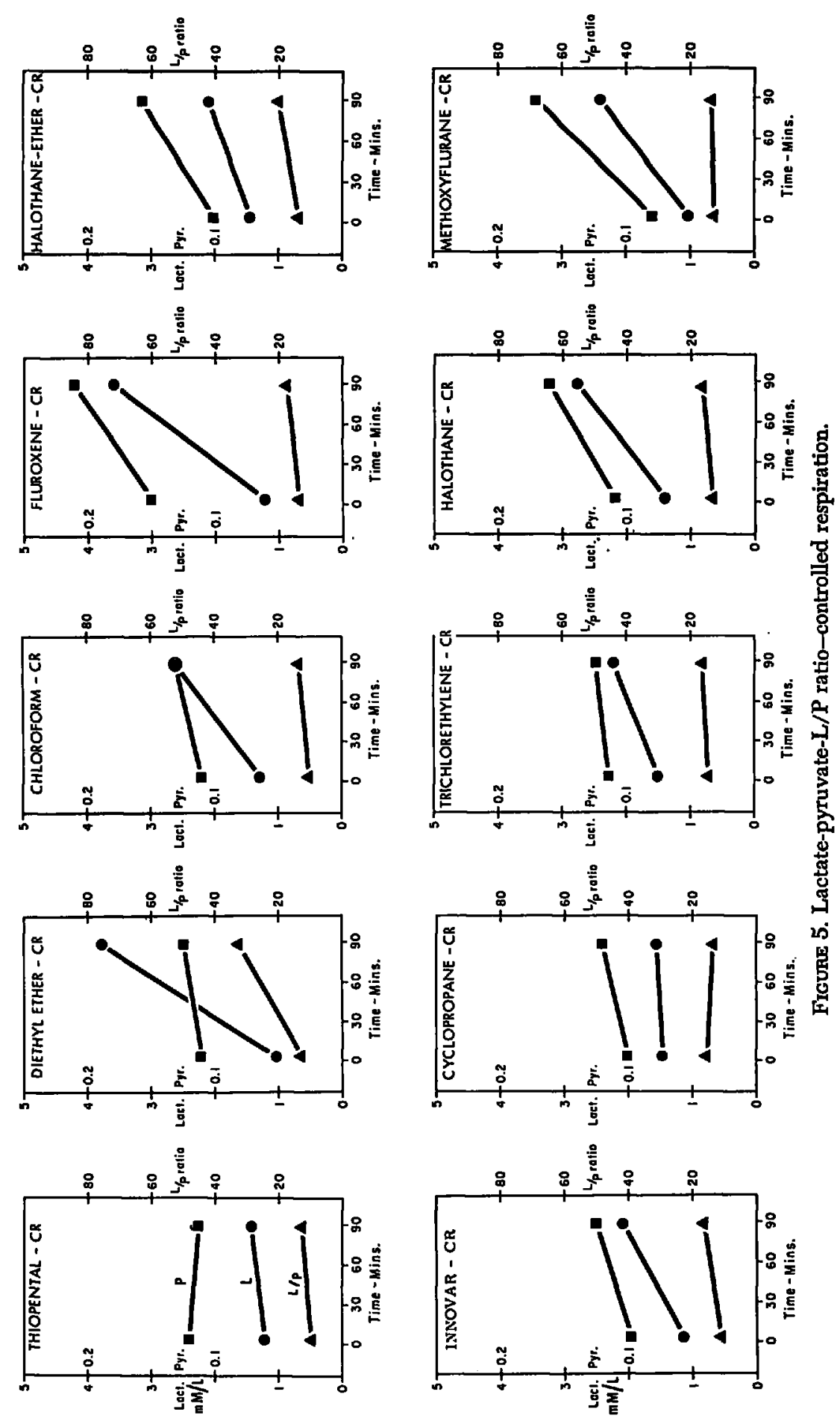

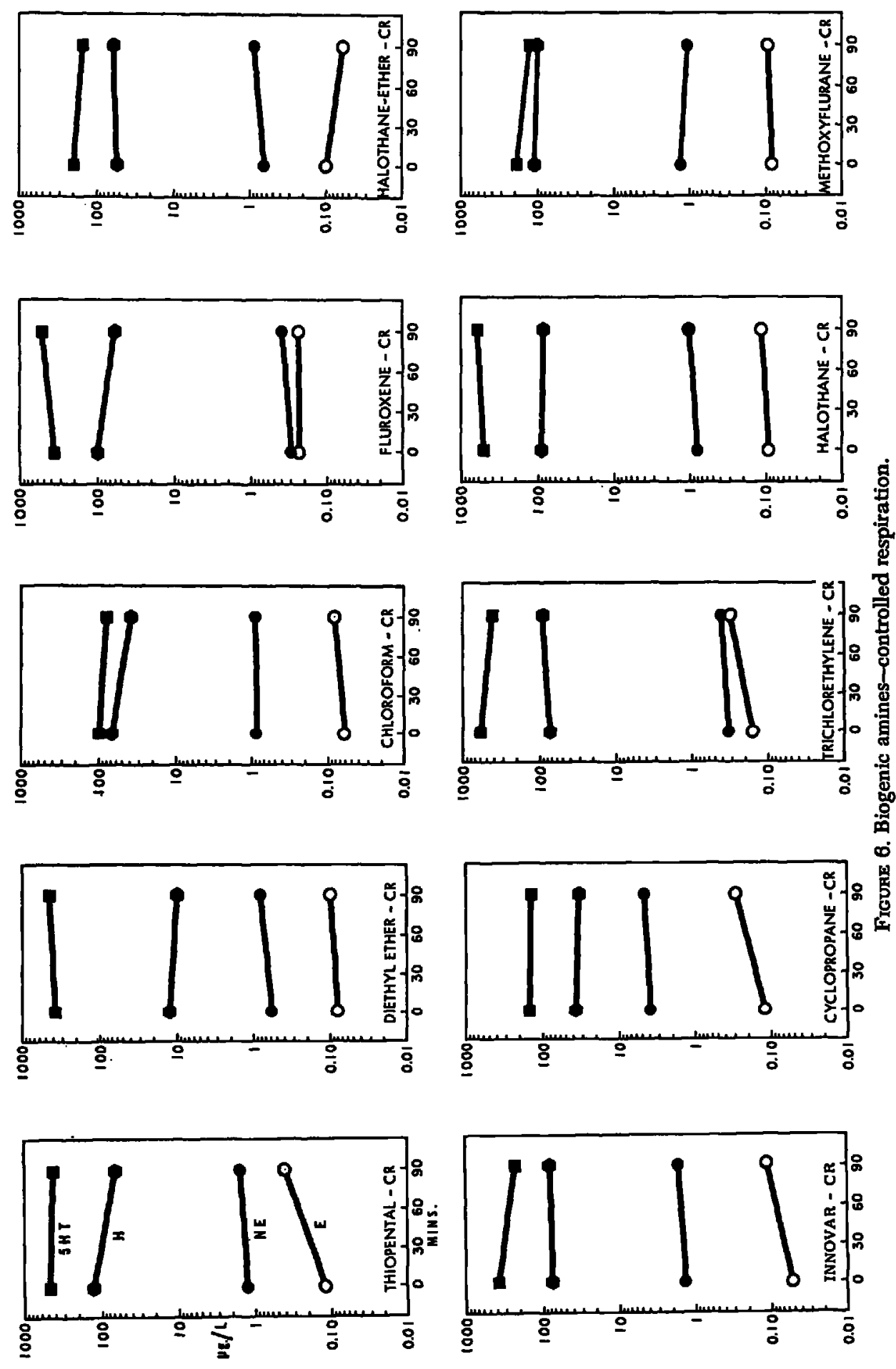


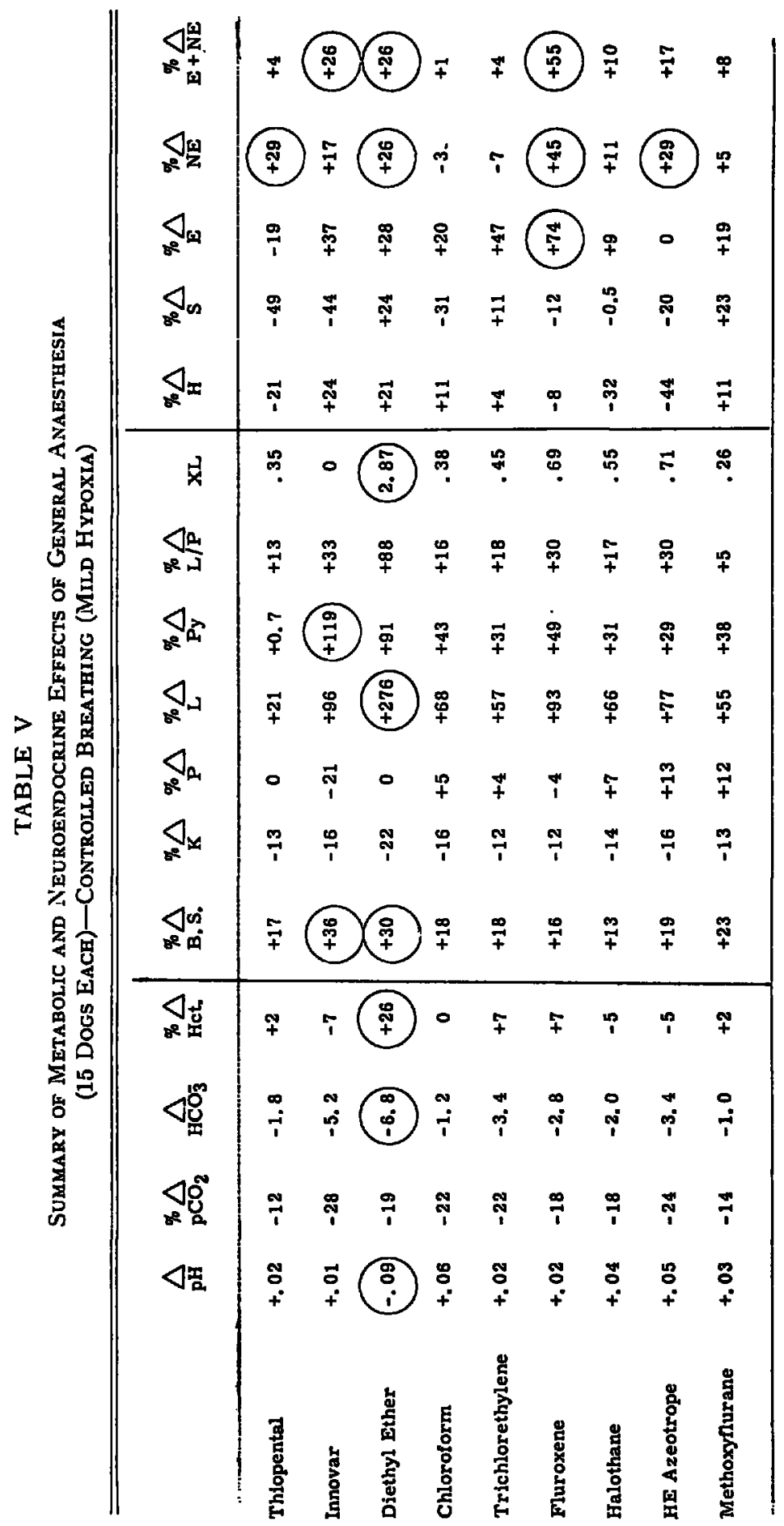



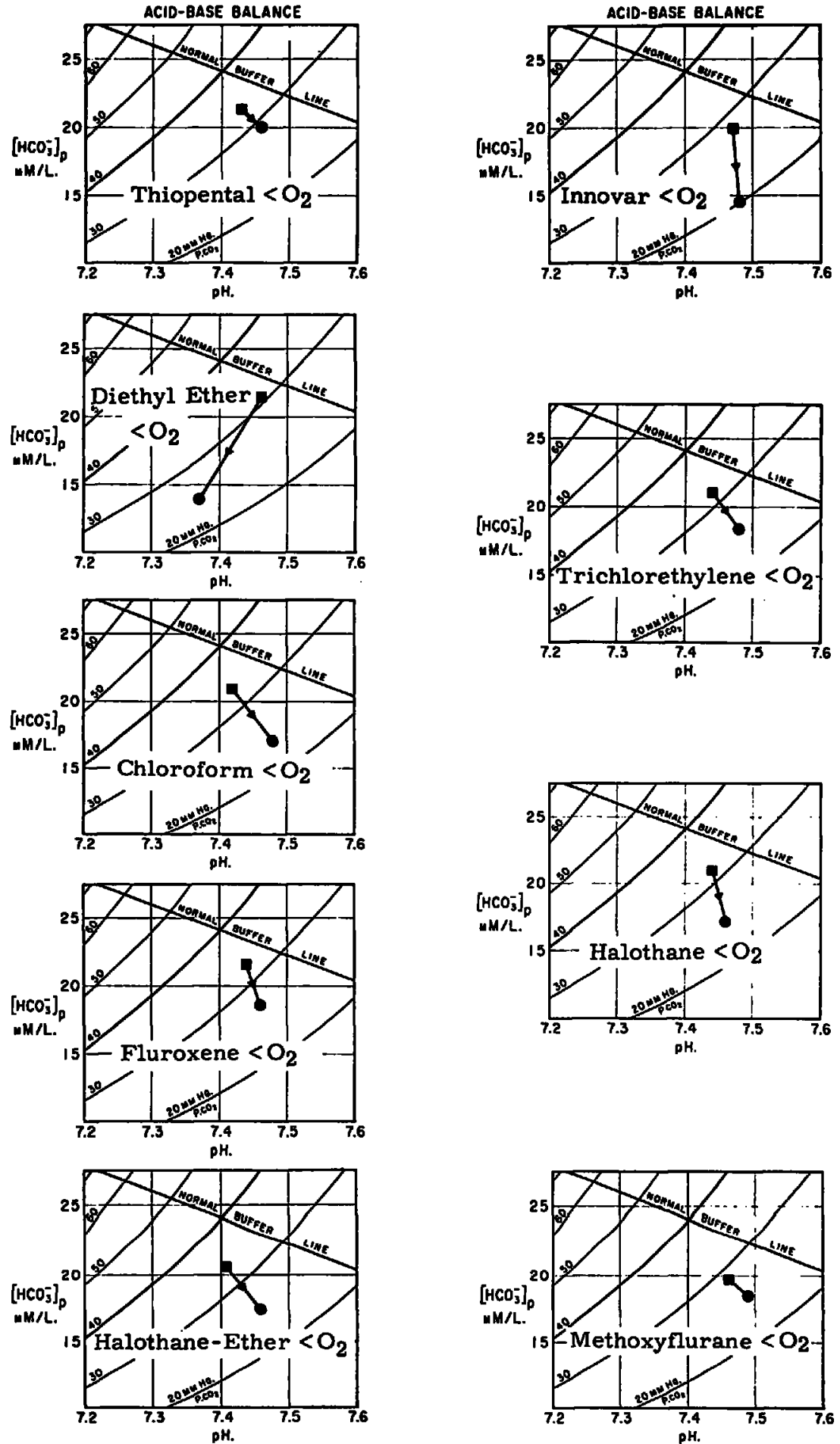

Fxcure 7. Acid-base balance-mild hypoxia. 

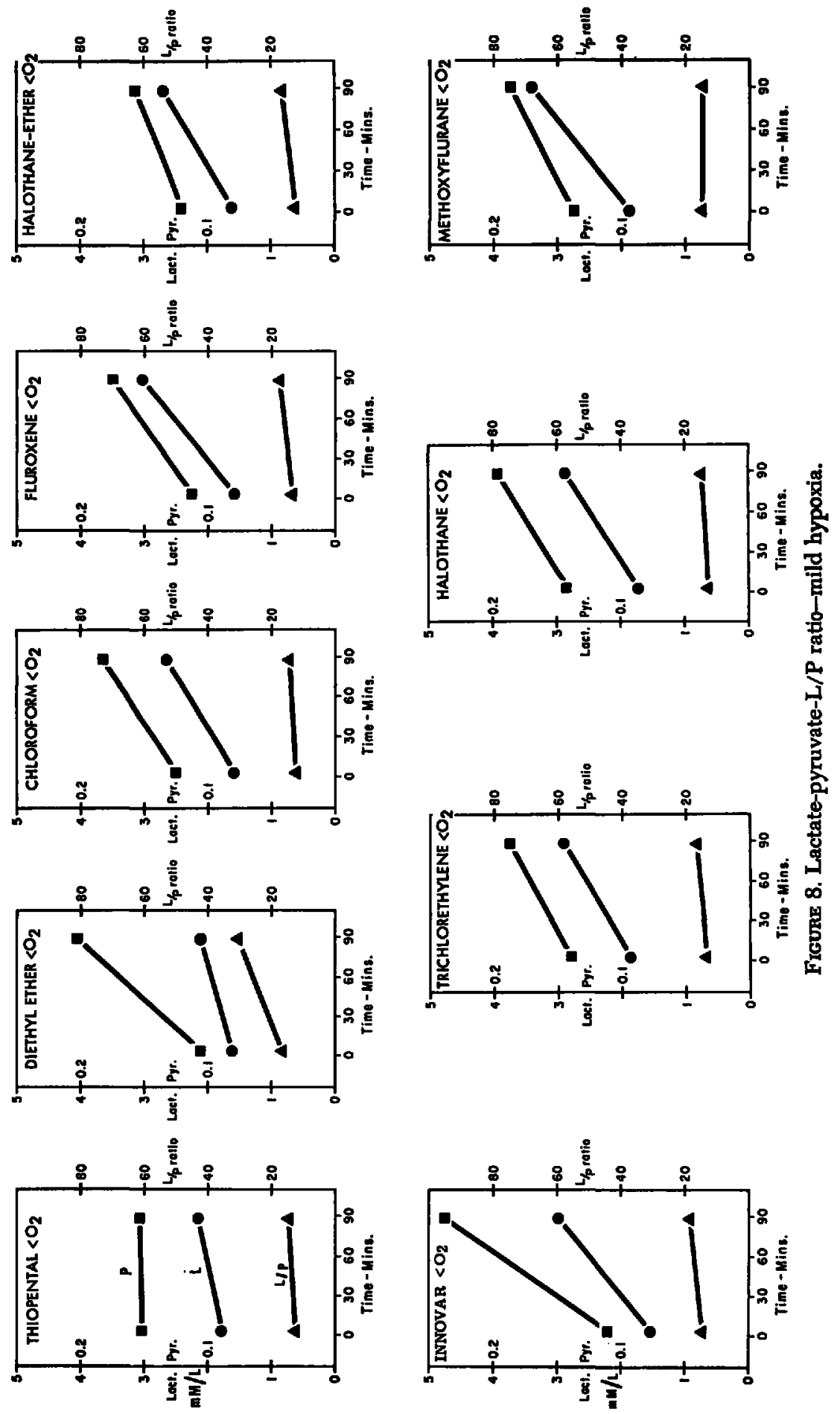

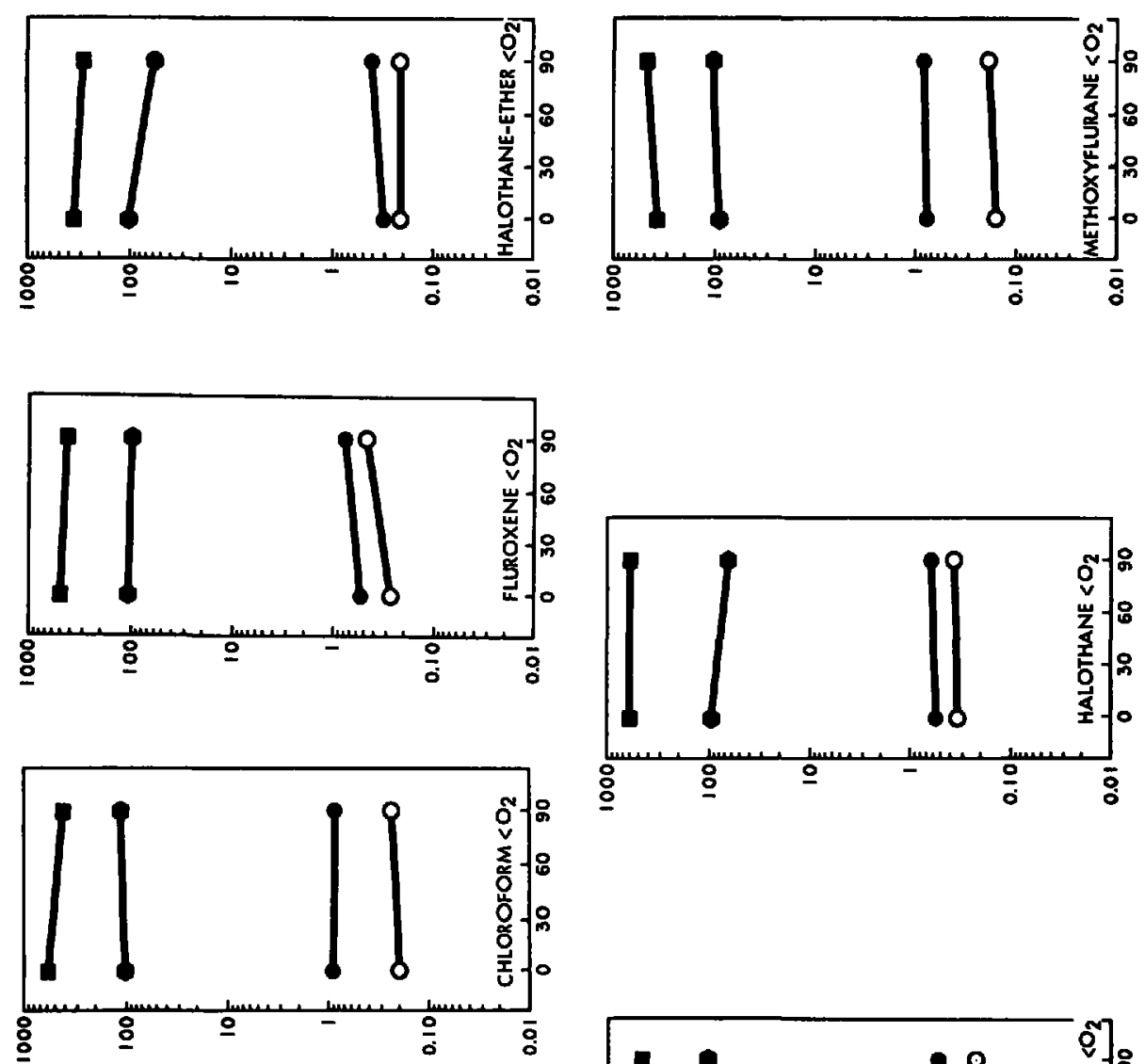

范
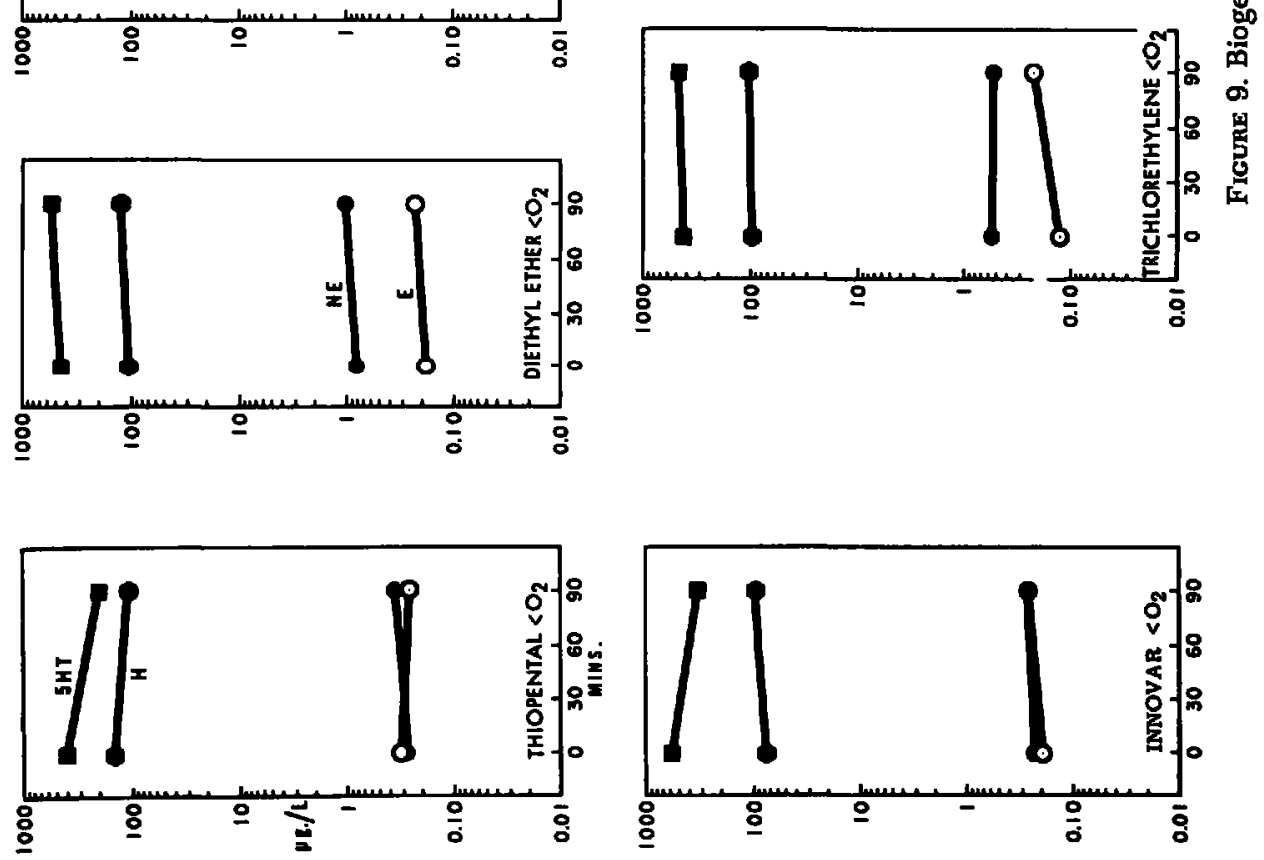
During the maintenance period of anaesthesia $\mathrm{pH}$ was $\sim 7.45$ throughout except with diethyl ether which caused a reduction, $P_{\mathrm{aCO}_{2}}$ decreased slightly in all the tests, and plasma bicarbonate was reduced by diethyl ether only ( 20.8 to 14.0 ). Blood sugar rose ( $>20 \%$ ) with Innovar, diethyl ether, and methoxyflurane; serum potassium decreased slightly in all tests (12 to $22 \%$ ); serum inorganic phosphorus showed no appreciable changes. Whole blood lactate was elevated with all agents, especially Innovar, diethyl ether, and fluroxene, and whole blood pyruvate was elevated with all agents, especially with Innovar and diethyl ether. $\mathrm{L} / \mathrm{P}$ ratio was elevated with diethyl ether (88\%), and excess lactate appeared with diethyl ether only ( $>2 \mathrm{mM} / \mathrm{L}$.). There were no appreciable changes in the whole blood histamine or serotonin. Epinephrine was elevated with Innovar, diethyl ether, trichlorethylene, and fluroxene ( $>25 \%$ ); norepinephrine was increased slightly with all anaesthetics except chloroform, trichlorethylene, and methoxyflurane, and total catecholamines increased ( $>25 \%$ ) with Innovar, diethyl ether, and fluroxene. Blood water decreased $(>4 \%)$ with diethyl ether only. Thus, during mild hypoxia, the blood sugar elevation was more likely with methoxyflurane, and blood lactate and catecholamine elevation was more likely with Innovar. Otherwise, no appreciable changes were observed.

\section{Mild Hypercarbia (with Controlled Respirations; 95 Experiments)}

Data are summarized in Table VI and Figures 10, 11, and 12.

The mean control $\mathrm{pH}$ was 7.37 , and $P_{\mathrm{aCO}_{2}}$ was 42 . During maintenance of anaesthesia, $\mathrm{pH}$ and $P_{\mathrm{acO}}$ did not change appreciably, while the plasma bicarbonate decreased slightly with diethyl ether only. Haematocrit rose slightly with diethyl ether; blood sugar was elevated with Innovar, diethyl ether, and chloroform; serum potassium always decreased slightly; and serum inorganic phosphorus always increased. Whole blood lactate rose with diethyl ether and fluroxene only, whereas there were no appreciable changes of whole blood pyruvate. The L/P ratio rose appreciably with diethyl ether only, and slight excess lactate occurred with diethyl ether $(>1 \mathrm{mM} / \mathrm{L}$.). Histamine decreased except with fluroxene, while serotonin rose with trichlorethylene and fluroxene. Epinephrine increased with diethyl ether (38\%), thiopental (16\%), halothaneether azeotrope (48\%), and methoxyflurane (16\%); norepinephrine increased with diethyl ether (25\%), halothane (25\%), and halothane-ether azeotrope (21\%), and total catecholamines did not rise appreciably with any of the anaesthetics, but the administration of carbon dioxide appeared to cause an over-all elevation of the blood level. Blood water was reduced by diethyl ether only. Thus, when a small amount of carbon dioxide was administered, the only obvious difference from the other three groups of tests was the somewhat greater release of catecholamines.

\section{Discussion}

During the administration of general anaesthesia there are many variables which require monitoring in order to detect and correct abnormalities. Some involve only simple clinical techniques such as recording of the blood pressure, pulse rate and pressure, and central venous pressure, which give useful data on 


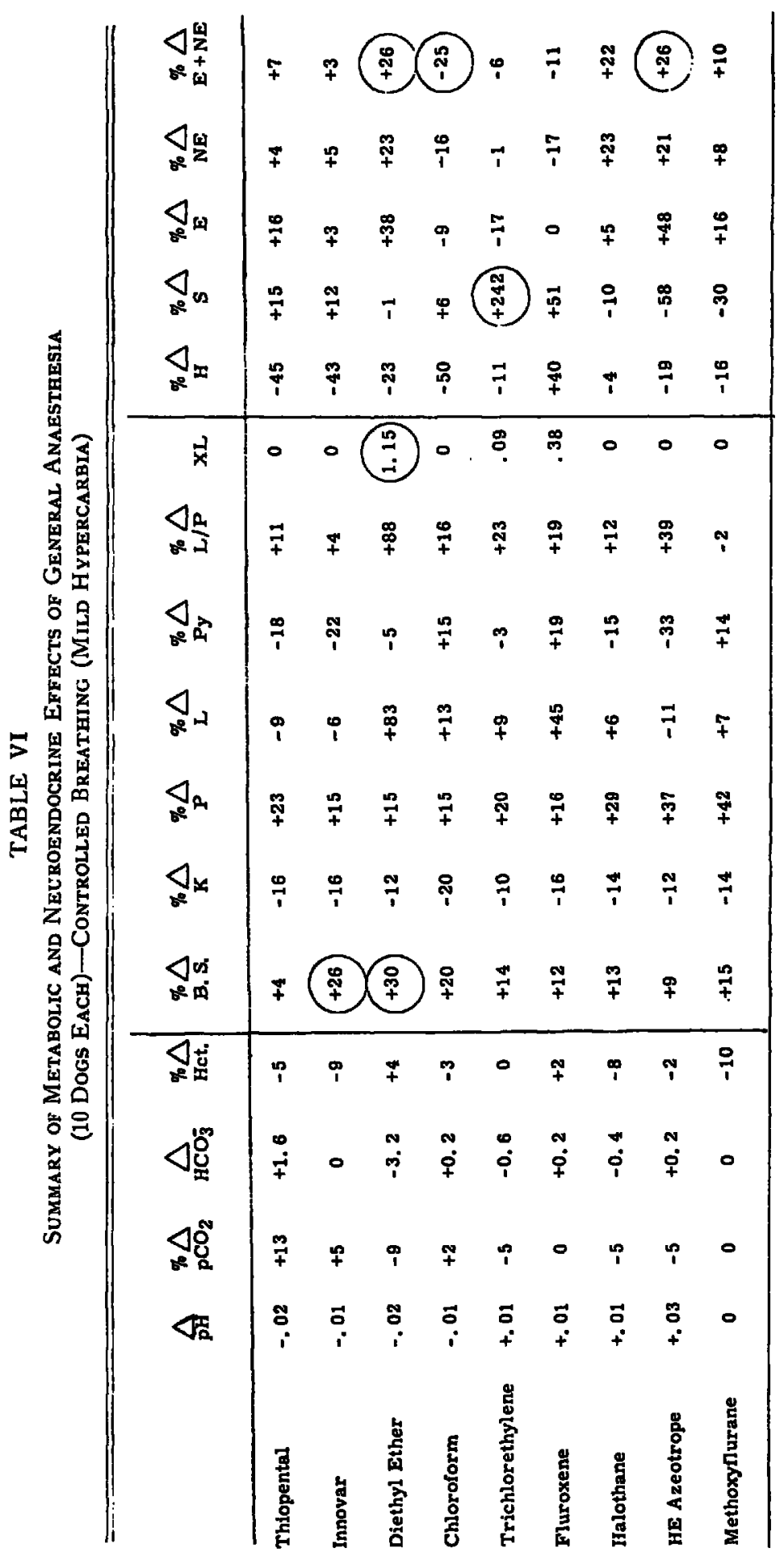



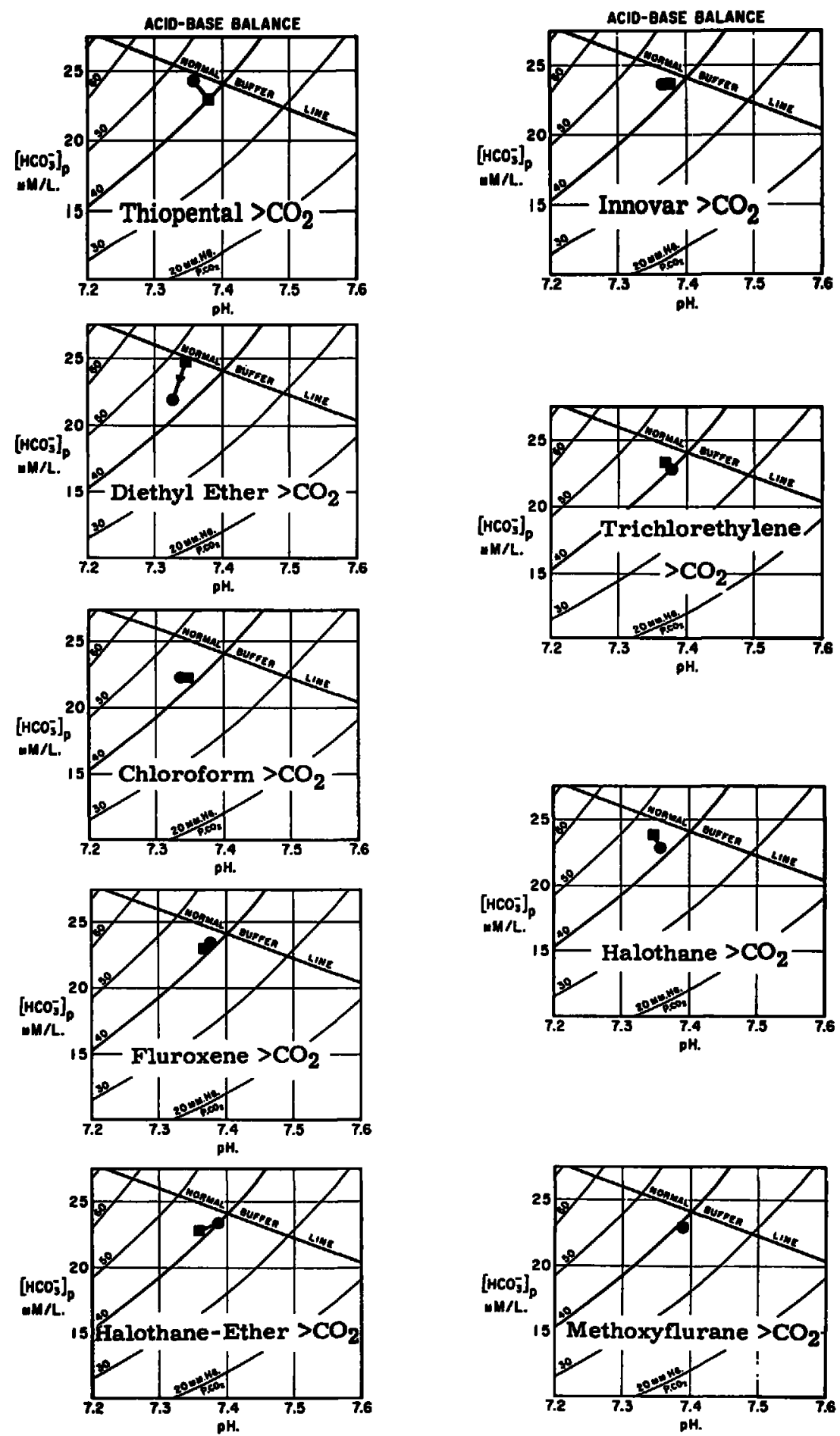

Ficure 10. Acid-base balance-mild hypercarbia. 

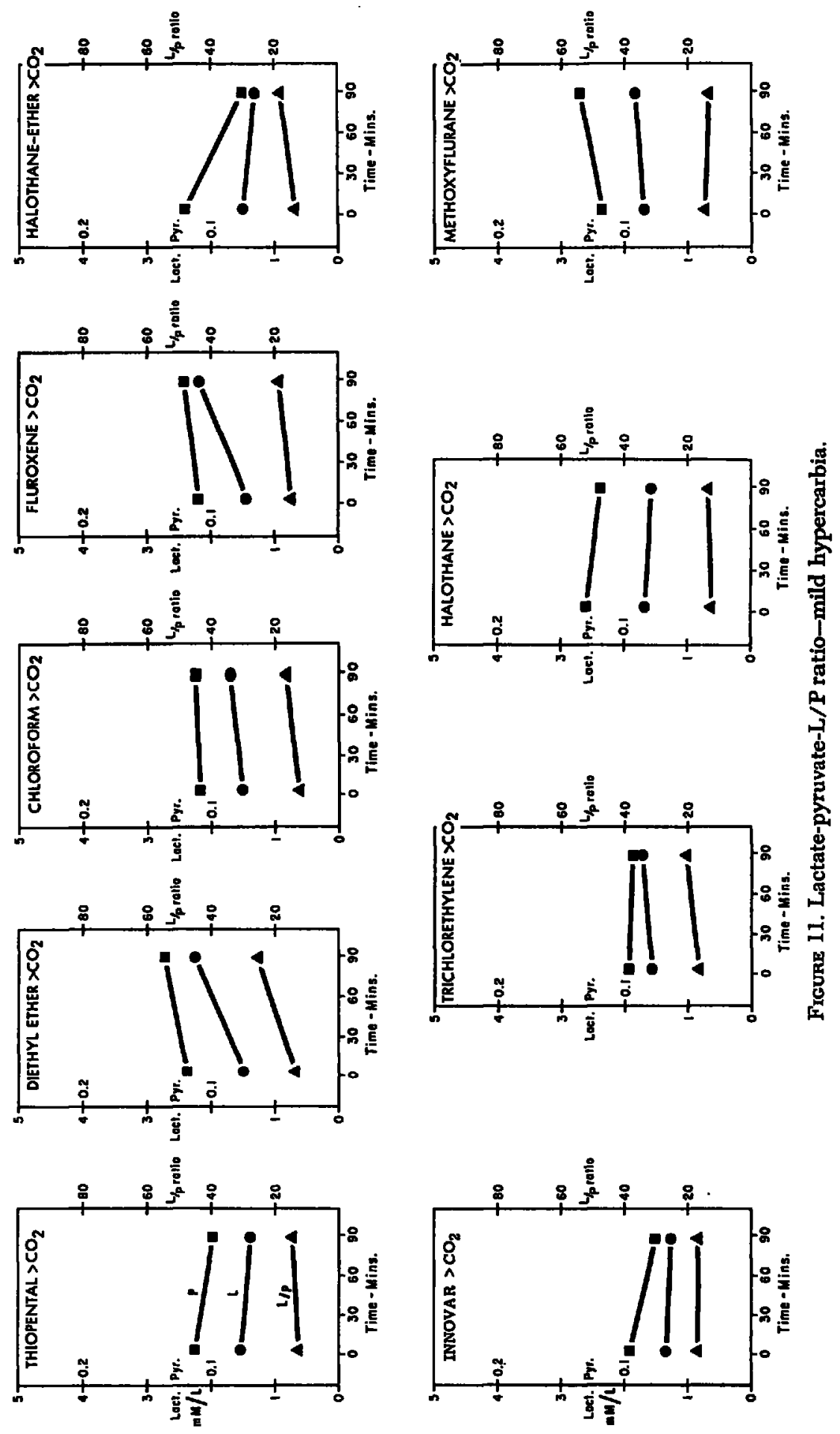

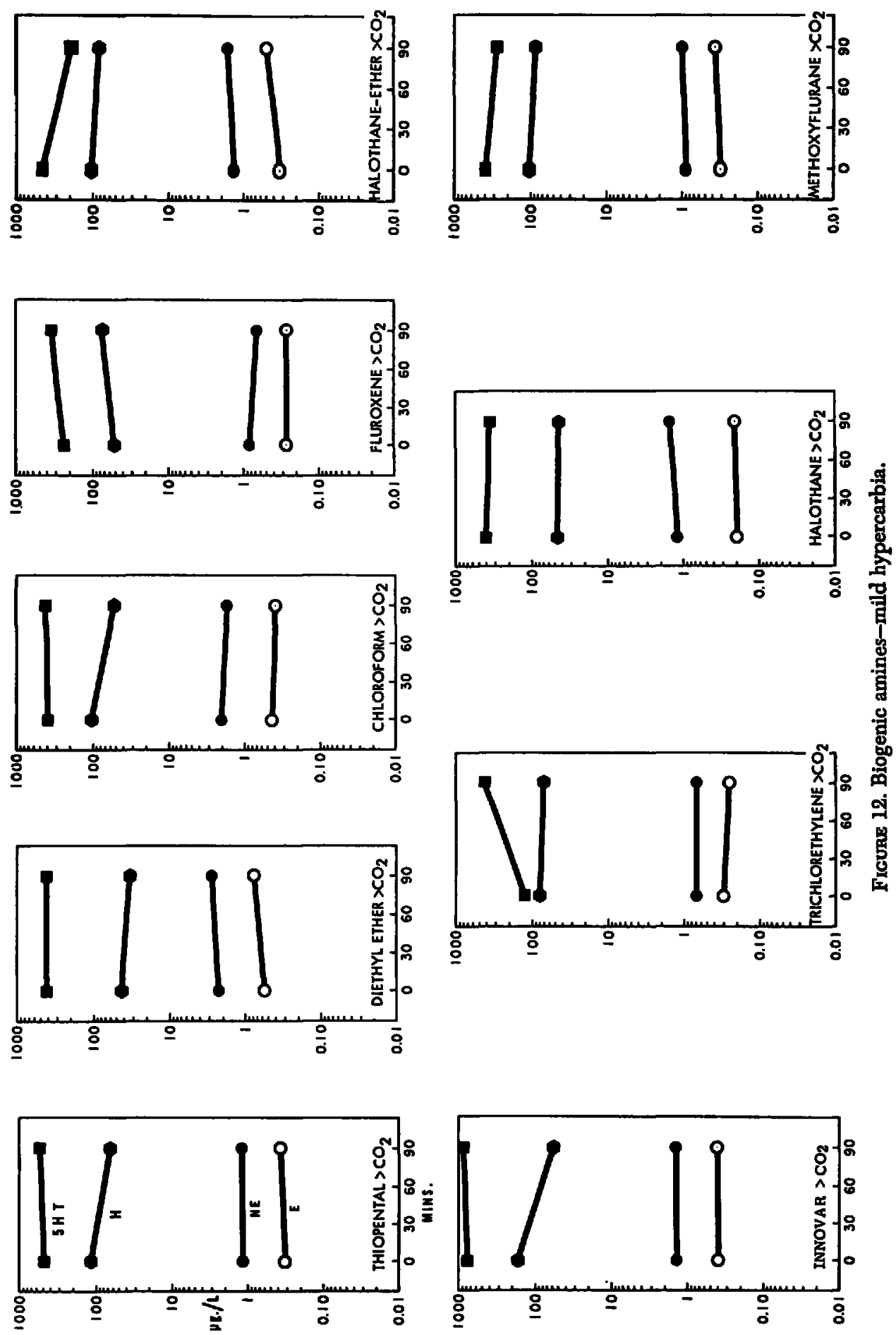


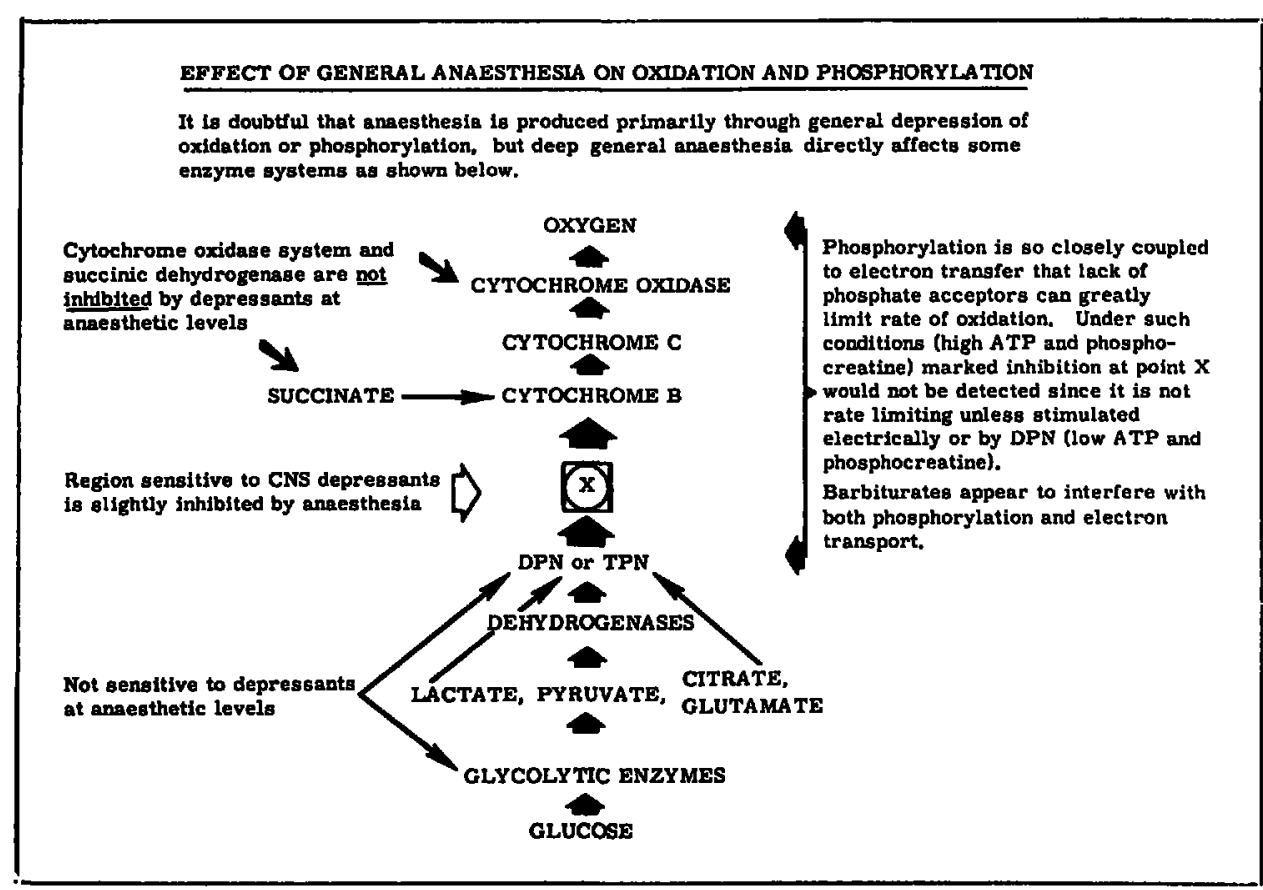

Frcune 13. Effect of general anaesthesia on oxidation and phosphorylation according to Hunter and Lowry (ref. 36).

perfusion and cardiac efficiency; ${ }^{23-25}$ measurement of the urine output gives clues as to visceral organ perfusion; ${ }^{26-28}$ and measurement of the rate and depth of respiration alerts the anaesthesiologist to effects on the primary physiological functions. ${ }^{29}$ Others involve biochemical assays which reveal alterations in neuroendocrine and metabolic functions.

It is now realized that the neural and endocrine systems are closely related and integrated via the hypothalamus, pituitary and adrenal glands, and other sources of hormones, each reacting on the other as well as on the whole organism. This extends to the cellular level and the maintenance of a "microhomeostasis." The delicate balance produced by the reciprocal activity of various neurohormones at various neural receptor areas leads to great complexity, apparent paradoxes, and difficulty in experimental elucidation. ${ }^{31}$ Norepinephrine, dopamine, acetylcholine, serotonin, histamine, L-glutamate, and gamma-amino butyric acid are examples of such neurohormones having multiple actions and sites of activity. ${ }^{\mathbf{2 2 - 8 5}}$

All anaesthetics, when administered in a dose sufficient to produce deep sensory deprivation, apparently decrease the production of high-energy phosphate bonds and decrease all neuronal activity-with accompanying decreases in oxidation being largely secondary to the decreased utilization of ATP $^{36}$ (see Fig. 13). The decrease in neuronal activity may be the result of special sensitivity to these drugs at synapses in general (where mitochondria are concentrated), or at synapses of the respiratory and vasomotor centers in the medulla. For this reason, Quastel now believes that the metabolism of synaptic tissue or specific regulating nerve centers might be the most sensitive to anaesthetic drug depres- 
sion. ${ }^{37}$ Hunter and Lowry stated that it is equally plausible that specific transmission mechanisms are inhibited by anaesthetic agents. These views are fundamental to the crucial explanation of the mechanism of anaesthesia. ${ }^{86}$

In man at least, it appears as if some of the metabolic and neuroendocrine changes might in fact be initiated before anaesthetic and surgical stresses have been applied.98 Premedicant and antisialogogue drugs can also influence the physiological and pharmacological responses to anaesthesia and its neuroendocrine reactions. ${ }^{30,40}$ For these reasons, no premedicant drugs were used in this study. Psychic trauma and fear are known to release histamine and catecholamines into the circulation and produce a labile blood pressure, tachycardia, skin disorders, fever, and vomiting, as well as bizarre behaviour. Indeed, epinephrine and histamine intoxication have been implicated in the aetiology of some chronic mental disorders. ${ }^{2}$ If appreciable alterations in the blood levels of these two biogenic amines alone could be demonstrated consistently, the excitement during induction and emergence with some anaesthetics, and the bulk of the biochemical and physiological alterations which appear during maintenance of anaesthesia could perhaps be explained in large part. However, by modern methods of measurement, such changes do not in fact appear to occur consistently, at least during the skilful administration of the drugs which produce general anaesthesia (in the absence of severe hypoxia and/or hypercarbia).

\section{Histamine and Serotonin}

Until recently, it was not known whether blood levels of histamine and serotonin were affected by the common general anaesthetics, nor were extensive attempts made to inquire into these. Although it is believed that histamine may be released from various tissues (skin, intestines, and lungs) into the general circulation by such commonly used ancillary drugs as atropine, opiates, and d-tubocurarine, causing skin reactions and hypotension and perhaps nausea and vomiting, consistent changes have not been demonstrable by blood assays in man, ${ }^{41}$ whereas animal experiments (dogs) have shown a striking increase. ${ }^{42,43}$ It has been suggested that if the blood assay of histamine falls in man in response to a histamine-releasing substance (such as d-tubocurarine) the histamine may have been taken up rapidly by histamine effector end organs such as the smooth muscle of cutaneous arterioles, bronchial musculature, and the gastric mucosa.41

Aviado has proposed that histamine participates in the pathogenesis of shock due to trauma to skeletal muscles and the lungs. When histamine is released into the systemic circulation in response to severe trauma, marked peripheral vasodilation occurs, followed by a reduction of venous return to the heart and a reduction of cardiac output. The hypotensive action of histamine is immediately accompanied by the release of catecholamines and potassium ion, and partly by a positive inotropic action of histamine. On the other hand, if histamine is released in the bronchial circulation, bronchial constriction may occur and systemic shock may develop by stimulation of "histaminergic" receptors in the airways, supplied by the vagus nerves, or else histamine released from the mast cells intimately related with the pulmonary vessels or transferred from the bronchial circulation can cause capillary congestion, pulmonary oedema, and severe hypoxaemia."4 
In our experiments, there were no appreciable consistent changes in the blood histamine level that could be correlated with the experimental conditions.

Serotonin (5-hydroxytryptamine) can also cause widespread disturbances in the body of man and dogs. It has sustained direct vasoconstrictor action which is preceded by a von-Bezold-like reflex (bradycardia and hypotension). Transient autonomic ganglionic block occurs, which is followed by a prolonged depressor response due to peripheral inhibition of neurogenic vasoconstriction (that does not antagonize norepinephrine action) and which is of lesser degree than the pressor response. Reflex and central respiratory stimulation also occur, producing hyperpnoea and a direct and reflex increase in bronchiolar tone, especially in asthmatic subjects. The latter can be suppressed by L.S.D. 25 and by atropine. Serotonin has a powerful antidiuretic effect due to both a reduced glomerular filtration rate and a direct increase in tubular reabsorption of water. It may contract the urinary bladder as well as the pupil, uterus, and intestines. Roles in haemostasis and blood-clot retraction have also been described, and serotonin appears to participate in such important phenomena as acute inflammation and the production of pain. Although serotonin is present in very large amounts in the body in certain abnormal conditions, it undoubtedly participates in normal metabolism since 5 to $10 \mathrm{mg}$. of its excretory product is present daily in the urine of healthy humans..$^{45-48}$

No assay work on serotonin whole-blood or plasma levels had been conducted during general anaesthesia until recently. ${ }^{40} \mathrm{~A}$ study by Aston, Dan, and Greifenstein found rather variable changes in the venous blood serotonin levels during thiamylal sodium, cyclopropane, and halothane anaesthesia. The changes with halothane were considered significantly greater than "normal."50

In the present study, Innovar anaesthesia caused a moderate rise in the serotonin estimations when ventilation was not fully augmented, and trichlorethylene anaesthesia caused a significant rise when 2.5 per cent carbon dioxide was administered, but the variation was great with all anaesthetics. Therefore, it is probably not valid to attribute the alterations to an effect of the anaesthetics per se, unless it can be shown that serotonin is released from blood platelets, brain, or other tissues into the plasma by these anaesthetic agents, since this biogenic amine appears to be maintained or stored in cells in a manner such that it neither is destroyed by enzymatic action nor is pharmacologically active, as norepinephrine is. ${ }^{48}$

\section{Catecholamines}

The sympatho-adrenal system is stimulated by stress and fear during wakefulness, which can be demonstrated by alterations in behaviour, by physical signs, and by an appreciable rise in circulating epinephrine, ${ }^{88}$ the principal hormone secreted by the adrenal medulla. ${ }^{1}$ Norepinephrine is the mediator released at postganglionic nerve endings under similar circumstances, and is the primary endogenous substance which can cause peripheral vasoconstriction in response to stress and drugs, provided that sufficient glucocorticoids and other adrenocortical steroids (aldersterone, estradiol, dehydroepiandrosterone) can be released or are available to mobilize free fatty acids from adipose tissue and glucose from the liver. ${ }^{40,51,52}$ 
It has been reported by a few workers that diethyl ether and perhaps cyclopropane anaesthesia produce a similar response during deep anaesthesia, and that the release of norepinephrine is appreciably greater than that of epinephrine. ${ }^{6,53-65}$ Some reports deny such a response, particularly during light anaesthesia. ${ }^{56,67}$ Some experiments have also demonstrated that thiopental, halothane, and methoxyflurane do not cause the release of catecholamines in the absence of hypercarbia or severe haemorrhage. ${ }^{6,57-50}$ The differences in results have been attributed to insensitivity or lack of specificity of the chemical tests employed."2

In this study, the catecholamine estimations were made by the trihydroxindole method, which is the preferred technique when epinephrine ond norepinephrine values are to be distinguished by differences of fluorescence. ${ }^{22}$ This method is of sufficient sensitivity to detect $.001 \mu \mathrm{g}$. of epinephrine and $.003 \mu \mathrm{g}$. of norepinephrine in plasma elutes. The fluorometric separation of epinephrine and norepinephrine carries an error of less than \pm 5 per cent, and analysis of duplicate samples varies less than \pm 10 per cent. The recovery of epinephrine is approximately 85 per cent $( \pm 20)$, and the recovery of norepinephrine is approximately 90 per cent $( \pm 10)$. In over 450 duplicate control estimations in our study the mean plasma epinephrine values varied between .11 and $.34 \mu \mathrm{g} . / \mathrm{L}$., and the mean control values of norephinephrine varied between .55 and $1.31 \mu \mathrm{g} . / \mathrm{L}$. among the four groups of experiments.

Diethyl ether was the only anaesthetic which showed a consistent rise in both catecholamines. Thiopental anaesthesia was associated with a rise in all experiments except the mild hypoxic group, in which the mean epinephrine level decreased, while the mean norepinephrine level increased. During cyclopropane anaesthesia, norepinephrine rose slightly with and without mild hypercarbia, but the plasma epinephrine rose only in the absence of hypercarbia. The halothaneether azeotrope always increased the plasma norepinephrine level somewhat, while the epinephrine level rose only in the presence of slight hypercarbia. Trichlorethylene caused a rise in epinephrine and norepinephrine, but only in the absence of slight hypercarbia. There were no consistent appreciable changes with the remaining general anaesthetics.

Our results suggest that only with diethyl ether, or in the presence of hypoxia or hypercarbia, are clinically significant abnormalities seen.

\section{Blood Sugar and Serum Inorganic Phosphorus}

The only consistent well-known metabolic changes that appear during general anaesthesia are the elevations of the blood sugar and serum inorganic phosphorus. ${ }^{60,61}$ These changes are probably less attributable to alterations of neuroendocrine secretion than to an increase in glycogenolysis in the liver that provides a continuous supply of glucose to the brain ( $50 \mathrm{mg}$. glucose $/ \mathrm{kg} . / \mathrm{min}$.) to maintain its steady oxygen consumption for normal metabolism $\left(30 \mathrm{ml} . \mathrm{O}_{2} / \mathrm{kg} . / \mathrm{min}\right.$.) . Decreased utilization of glucose by the tissues, or "glucose intolerance," decreased elimination of glucose through the kidney, and decreased utilization of highenergy organic phosphates assist this metabolic "goal" to maintain cerebral homeostasis. $80,82,08$

In this study, an appreciable elevation in blood sugar was associated with two particular anaesthetic agents-Innovar and diethyl ether. This effect did not 
usually coincide with an appreciable elevation of catecholamines in the blood plasma. The rise in serum inorganic phosphorus appeared to be related only to the occurrence of respiratory acidosis, whether resulting from the endogenous accumulation or the administration of carbon dioxide, which supports the thesis of an extra-renal response to acid-base balance disturbance. ${ }^{7,64}$ The predominant effects of diethyl ether on blood sugar and serum inorganic phosphorus in the absence of gross disturbances in the lactate, pyruvate, and citric-acid cycle may be due to an alteration in tissue phosphorylation rather than to depression of tissue oxidation. ${ }^{63}$

\section{Serum Potassium}

A reduction of serum potassium (and reduction of its excretion in the urine) has been reported during diethyl ether. ${ }^{85,}{ }^{68}$ This effect cannot be explained by the occurrence of severe extracellular fluid-volume deficits because the animals in this study were not subjected to surgical trauma. ${ }^{67}$ We have consistently observed a slight reduction of serum potassium during all intravenous and inhalation general anaesthestics following thiopental induction, provided that no premedicant drugs have been employed and that pulmonary ventilation was augmented adequately. ${ }^{68-71}$ This change appears to be a brief characteristic response to drug-induced total sensory deprivation, which may cause temporary migration of the potassium ion from the plasma into the tissues. Mild respiratory acidosis does not appear to alter this response, whereas the serum potassium may be elevated during and after severe carbon dioxide retention. ${ }^{72}$ Since the plasma contains a very small part of the body potassium, it is probably not valid to attach great significance to moderate changes in the serum. However, even small alterations cannot be ignored if pulmonary ventilation is depressed because potassium ion concentration in the blood is normally very stable and may shift rapidly from skeletal muscle to such a vital area as cardiac muscle via the blood without being evident unless serial measurements are made at short intervals. ${ }^{73}$

\section{Lactate, Pyruvate, L/P Ratio, and Excess Lactate (XL)}

According to Huckabee, the ratio of lactate to pyruvate concentrations in the blood and the calculation of "excess lactate" (XL, defined as $\left(L_{n}-L_{0}\right)-\left(P_{n}-P_{0}\right)$ $\left(L_{0} / P_{0}\right)$, where $L_{\mathrm{n}}$ and $P_{\mathrm{n}}$ are the induced values and $L_{0}$ and $P_{\mathrm{o}}$ are the normal or control values of lactate and pyruvate) provide an index of tissue hypoxia. ${ }^{74-76}$ Excess lactate $(>0.2 \mathrm{mM} / \mathrm{L}$.) was said to indicate abnormal accumulation of lactate in excess of that from the lactate/pyruvate obtained under normal conditions. Huckabee derived the $\mathrm{XL}$ formula for calculation of "excess lactate" from the mass law as it applies to the enzymatic oxidation-reduction of lactate in a closed system according to the equation:

$$
\text { Pyruvate }+\mathrm{DPNH}+\mathrm{H}^{+} \stackrel{\mathrm{LDH}}{\rightleftarrows} \text { Lactate }+ \text { DPN. }
$$

The basic postulates of the XL formula are that the lactate/pyruvate ratio measures the reduced diphosphopyridine nucleotide $\left(\mathrm{DPNH}_{2}\right)$-oxidized diphosphopyridine (DPN) ratio, assuming that lactate is only formed or converted to 
pyruvate, and that it defines the state of tissue oxygenation. This reaction is catalysed by a group of proteins called lactate dehydrogenase (utilizing nicotinamide adenine denucleotide (NAD) as a co-enzyme), and is dependent upon the availability of molecular oxygen to maintain a normal $\mathrm{DPNH}_{2} / \mathrm{DPN}$ ratio. As molecular oxygen becomes grossly deficient or lacking, lactate accumulates, the $L / P$ ratio rises, and $X L$ increases, reflecting the extent to which electron transfer is failing. The administration of glucose, lactate, and pyruvate intravenously does not cause "excess lactate" in the presence or normal oxygenation, ${ }^{74}$ whereas during breathing of a hypoxic gas mixture $\left(8 \% \mathrm{O}_{2}+92 \% \mathrm{~N}_{2}\right)$ the rise in lactic acid far exceeds any apparent oxygen debt-which seems to be more closely related to change in $\mathrm{L} / \mathrm{P}$ ratio than to alteration in the blood level of lactic acid itself. ${ }^{76}$

Other manoeuvres may also induce excess lactate, such as mild exercise and administration of epinephrine. ${ }^{75}$ Broder and Weil have said an excess of lactate of more than $4 \mathrm{mM} / \mathrm{L}$. prognosticates a fatal outcome of humans and dogs in shock. ${ }^{77}$

Huckabee's thesis has recently been questioned because it is apparent that excess lactate is not an indisputable sign of anaerobiosis, and conversely that anaerobiosis can occur without the appearance of "excess lactate," and lactate measurements may not necessarily reflect severe tissue hypoxia unless the condition is virtually agonal. Olson points out that the concept of "excess lactate" assumes that the lactate/pyruvate ratio should remain constant in cells. ${ }^{78}$ However, Boxer and Devlin have established that there are at least two, and possibly more, pools of $\mathrm{DPNH}_{2} / \mathrm{DPN}$ in the cell-one in the cytoplasm and one in the mitochondria. ${ }^{79}$ These pools do not participate in direct transhydrogenation since external $\mathrm{DPNH}_{2}$ is poorly utilized by intact well-coupled mitochondria. A shunt metabolite, possibly malate, shuttles hydrogen between the cytoplasm and the mitochondria. Thus, the lactate/pyruvate ratio in the blood, which is determined by cytoplasmic lactic dehydrogenase, may or may not reflect the state of oxidation-reduction of mitochondrial $\mathrm{DPNH}_{2}$. This ratio depends upon the relative rates of entry of hydrogen into the cytoplasmic pool of pyridine nucleotide and exit via the mitochondrial shuttle system as shown below..$^{78}$

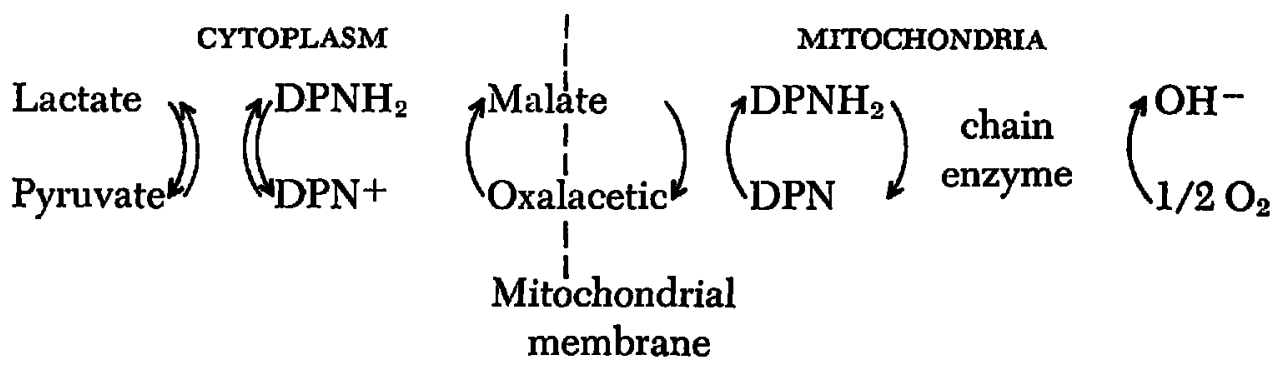

Greene has stated that diethyl ether and cyclopropane anaesthesia are accompanied by anaerobic carbohydrate metabolism that results in excess lactate. ${ }^{80}$ He has stated further that this effect was not due to the anaesthetics themselves, but rather to the concurrent release of catecholamines which cause a reduction 
of tissue-oxygen tensions. On the other hand, he has found no appreciable changes in lactate or pyruvate with thiopental-nitrous-oxide anaesthesia. During our experiments, all the general anaesthetics at times caused some elevation of lactate, L/P ratio, and "excess lactate" and variable changes in the pyruvate, but a significant effect could only be related to one anaesthetic-diethyl ether-and this effect was not directly related to alterations in the blood levels of the biogenic amines. We also noticed that while the administration of 2.5 per cent carbon dioxide appeared to elevate the catecholamine levels, no such change occurred with lactate or pyruvate. We also found that thiopental-nitrous-oxide did cause some elevation of the blood lactate which was not consistently associated with elevation of the catecholamines, while cyclopropane had no effect on the lactate and pyruvate concentration. It is important to emphasize that changes in lactate did not correspond to changes in the catecholamines with cyclopropane or ether except by chance, and that diethyl ether was the only general anaesthetic which caused the accumulation of "excess lactate" consistently. (See Table VII).

TABLE VII

Mean Excess Lactate (mM/L.)

\begin{tabular}{|c|c|c|c|c|}
\hline & $\begin{array}{l}\text { Spontaneous } \\
\text { breathing } \\
\text { (10 dogs each) }\end{array}$ & $\begin{array}{c}\text { Controlled } \\
\text { breathing } \\
\text { (11 dogs each) }\end{array}$ & $\begin{array}{c}\text { Controlled } \\
\text { breathing }<\mathrm{O}_{2} \\
(15 \text { dogs each) }\end{array}$ & $\begin{array}{c}\text { Controlled } \\
\text { breathing }>\mathrm{CO}_{2} \\
(10 \text { dogs each })\end{array}$ \\
\hline Thiopental & .452 & .327 & .354 & $\mathbf{0}$ \\
\hline Innovar & .284 & .591 & 0 & 0 \\
\hline Diethyl Ether & 2.731 & 2.550 & 2.867 & 1.154 \\
\hline Cyclopropane & .077 & 0 & & \\
\hline Chloroform & .291 & .669 & .379 & 0 \\
\hline Trichlorethylene & .172 & .488 & .453 & .092 \\
\hline Fluroxene & .458 & 1.531 & .685 & .377 \\
\hline Halothane & 0 & .646 & .554 & $\mathbf{0}$ \\
\hline $\begin{array}{l}\text { Halothane-Ether } \\
\text { Azeotrope }\end{array}$ & 0 & .697 & .714 & $\mathbf{0}$ \\
\hline Methoxyflurane & .158 & .214 & .263 & 0 \\
\hline
\end{tabular}

Alterations in blood lactate, pyruvate, L/P ratio, and "excess lactate" during clinical anaesthesia have not been adequately explained partly on account of the paucity of data on these estimations themselves, ${ }^{80-83}$ and also because there is a virtual absence of data on the concurrent estimation of related metabolic factors. Perhaps as more information becomes available regarding the stores and functional compartments where the biogenic amines may be held in cells in an active and inactive state, and regarding the role of the several phosphorylase systems which act as mediators for the transfer of impulses from the autonomic nervous system to various cell functions, we may be able to explain acute or longterm metabolic adjustments to the energy requirements of the tissue cells during and after the administration of a general anaesthetic. ${ }^{84}$ Haugaard and Hess point out that the cyclic AMP phosphorylase system is unique among enzymes 
in that it responds to a great variety of drugs at concentrations which result in discreet alterations in cellular function, and there is an apparent correlation between phosporylase activity, rate of glycogenolysis, and the activity of the sympathetic nervous system and sympathomimetic drugs. Since sodium and potassium have an important influence on membrane phenomena, these ions, together with calcium, may also affect these biological systems. ${ }^{85} \mathrm{~A}$ study of halothane anaesthesia on such a broad base has been reported by Suutarinen and associates, ${ }^{80}$ which gives us a much better idea of the interaction of various metabolites, than would an attempt to draw conclusions from estimations of excess lactate alone.

\section{Blood Water (See Table VIII)}

Besides water loss in the urine, feces, and sweating, the normal active human loses approximately $500 \mathrm{ml}$. of water (as vapour) from the lungs in 24 hours. Since dogs do not sweat, and because they have a much higher basal metabolism ( $7 \mathrm{ml} . \mathrm{O}_{2} / \mathrm{min} . / \mathrm{kg}$., as opposed to $4 \mathrm{ml} . \mathrm{O}_{2} / \mathrm{min} . / \mathrm{kg}$. in man), they lose a relatively larger amount of water in the urine and from the lungs by both breathing and panting.

During the administration of anaesthesia in a non-rebreathing system, the water vapour content of the atmosphere is not available to the lungs, whereas the expired gas is fully saturated with water. It is conceivable, therefore, that if the expired gas from the pulmonary airway contains seven per cent water (saturated air at $38^{\circ} \mathrm{C}$.) and a 25-kilogramme dog has a minute ventilation of 10 litres ( $350-400 \mathrm{ml} . / \mathrm{kg} . / \mathrm{min}$.) as arranged in these experiments, it is possible to lose in excess of $50 \mathrm{ml}$. of water during 90 minutes of anaesthesia. The only ready source of water in the lungs in these experiments is the circulating blood, containing 80 per cent water, which would amount to approximatly $1500 \mathrm{ml}$. water in the circulating blood of a 25-kilogramme dog. The only anaesthetic that appeared to cause an appreciable consistent reduction $(\sim 4 \%)$ in the wholeblood water was diethyl ether. This reduction would account for a loss of approximately $48 \mathrm{ml}$. water, assuming the dog's blood volume to be $80 \mathrm{ml} . / \mathrm{kg}$. It appears therefore that all of the water that was lost from the blood during the anaesthetic experiments can be accounted for by loss through the lungs. However, there have been other explanations: McAllister and Root showed that during diethyl-ether anaesthesia there is a reduction of plasma volume; ${ }^{87,88}$ Stewart and Rourke attributed this haemoconcentration to a shift of fluid out of the circulation into the extracellular fluid space; ${ }^{65}$ Robertson and Frazer recently attributed such a shift of water to the movement of sodium and potassium, ${ }^{89}$ and Crawford and Guadino showed that there is in fact an expansion of the extracellular fluid volume during the administration of diethyl ether, cyclopropane, and thiopental anaesthesia with nitrous oxide supplementation. ${ }^{90}$ They also found that the administration of isotonic saline solution (as was done in our experiments) causes a highly variable increase in extracellular fluid.

Many homeostatic mechanisms come into play when extra water is lost from the body, and tend to suppress excessive loss of cellular and interstitial water. The 


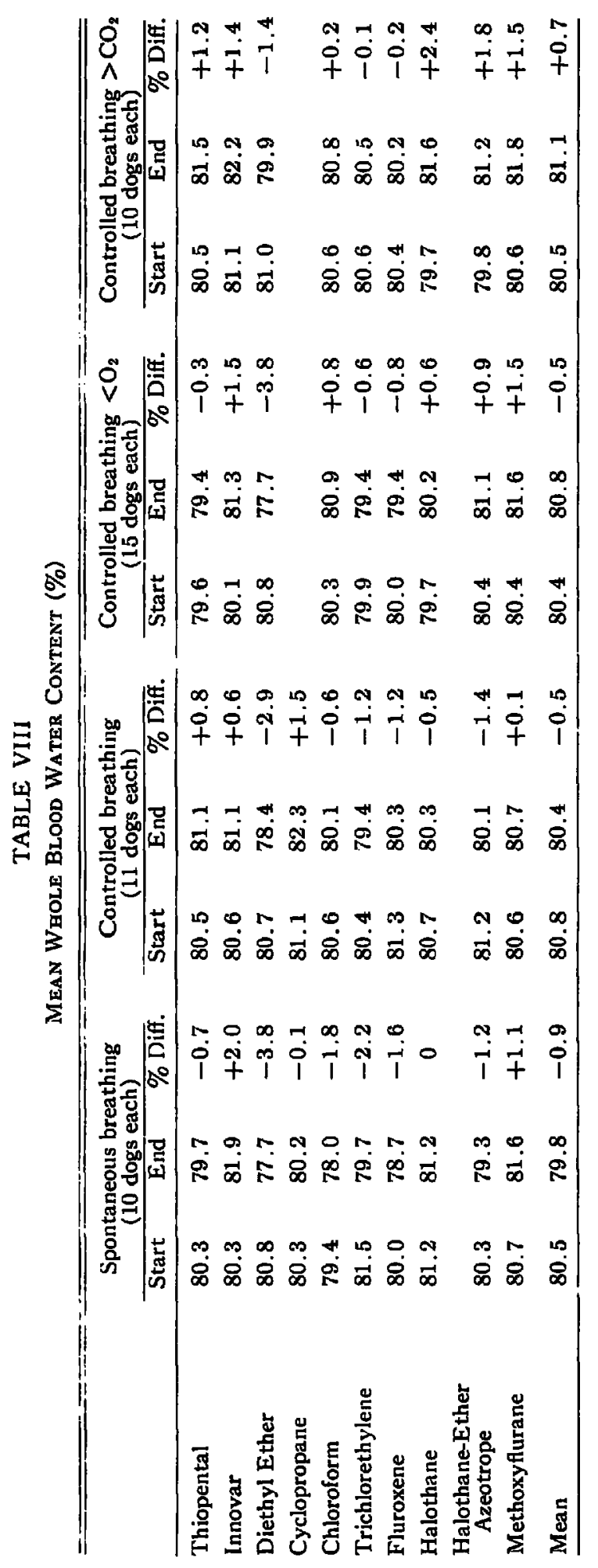


most obvious way is by the relative oliguria that develops promptly after a surgical plane of anaesthesia is reached, and is attributed to the action of antidiuretic hormone. ${ }^{.1-93}$ During ether anaesthesia, contraction of the spleen $^{94,95}$ and increased adrenocortical activity ${ }^{96}$ also may explain the occurrence of haemoconcentration. The striking point in this study was that diethyl ether was the only anaesthetic that caused an obvious reduction of the blood water, and all the reasons that have been sought to explain this do not apply to the general anaesthetic state, but rather to this particular anaesthetic agent.

\section{Haematocrit}

Alterations in circulating blood cell volume cannot be separated easily from changes in the circulating fluid volume due to the interplay of numerous factors, and the errors of measuring the two components are frequently larger than the differences that are observed under the experimental conditions. In the absence of fluid administration and gross changes in body temperature, haemoconcentration (haematocrit increased $>10 \%$ ) is known to occur invariably during anaesthesia with diethyl ether but hardly ever during the administration of other general anaesthetics. 97,88 This effect apparently becomes more prominent when surgical trauma is superimposed.98 ${ }^{99}$ The current most popular explanation for this change is that there is an increase in capillary permeability so that the circulating fluid is lost into the interstitial fluid spaces at the site of trauma. ${ }^{67}$ Since the total area of capillary endothelium in the body is relatively very large and its permeability to blood plasma is high, a considerable volume of fluid can be filtered or absorbed in a short time merely with rises or falls of the venous pressure. ${ }^{100}$ On the other hand, the spleen is considered as a large reservoir for red blood cells ${ }^{94,85}$ which may be added to the circulation during anaesthetic stress and produce haemoconcentration without a concurrent loss of circulating plasma. ${ }^{101}$ The pulmonary circulation may also "hold" a larger volume of blood during inactivity in the recumbent position or during general anaesthesia. ${ }^{102}$ It is conceivable that a considerable amount of water may diffuse out of the lungs during general anaesthesia administered in a non-rebreathing system and cause haemoconcentration as noted above. The release of catecholamines from the adrenal medulla and sympathetic nerve endings might also be implicated as a factor in the relative increase in cellular volume. 108,104

In the current study, diethyl-ether anaesthesia caused a consistent and appreciable increase in the haematocrit. This was due in part to the reduction of the blood-water content noted above. Since water loss can only account for less than half the increase in the haematocrit, splenic contraction is an explanation that cannot be ignored.

\section{Urine Excretion}

The frequent occurrence of oliguria during general anaesthesia is well known. ${ }^{28,105,108}$ This effect rarely persists in the absence of complicating surgical or pathological factors. ${ }^{107}$ Intrarenal vasoconstriction, shunting of blood from artery to vein through the junctional glomerular vessels causing a reduced glomerular filtration, and increased reabsorption of water and electrolytes have been attributed to a direct effect of anaesthesia. ${ }^{108}$ 
There was usually no appreciable reduction in the urine excretion during the initial 10 to 20 minutes of most of these experiments, regardless of which anaesthetic was administered. Thereafter, we observed a sharp and obvious oliguria with every anaesthetic agent except thiopental, fluroxene, and halothane. The oliguria was not directly related to the occurrence of hypotension. Thiopental consistently caused oliguria only in the mildly hypoxic dogs in the absence of hypotension; otherwise there were few instances of an obvious reduction of urine output with this agent. During fluroxene and halothane anaesthesia, urine suppression was exhibited in only a few dogs although hypotension ( $>25 \%$ ) almost always occurred with halothane, while with Innovar, diethyl ether, cyclopropane, chloroform, trichlorethylene, halothane-ether azeotrope, and methoxyflurane, urine suppression was frequently severe whether hypotension occurred or not. Our observations agree with Aprahamian and associates ${ }^{93}$ that thiopental anaesthesia does not cause an appreciable antidiuretic response; but, except perhaps in the case of fluroxene and halothane, the induction of anaesthesia with thiopental did not appear to attenuate the antidiuretic effect with other anaesthetics, as they claimed. The difference in results may be due to their brief period of observation. The release of catecholamines causing renal vasoconstriction has been implicated as a major reason for the oliguria, particularly during anaesthesia with diethyl ether and cyclopropane, ${ }^{109}$ but this explanation does not correlate well with our data on the catecholamine blood levels. The more plausible cause, which may be applied perhaps to all the general anaesthetics (except thiopental), is the release of antidiuretic hormone ${ }^{28,110}$ and alterations in electrolyte excretion, although these are not the only answers either, because oliguria still occurs during general anaesthesia in dogs that have been subjected to pituitary ablation. ${ }^{111}$

\section{Commentary}

It is apparent from the foregoing discussion that no matter how precisely an experiment is designed and observed, and no matter how much care is taken to control factors which cause extraneous variation, the true answers as to effects and causes can only be found if all the interacting parameters are known and observed. This is a vital problem in studying and understanding the biochemical and pharmacological effects of anaesthetics. This is the case with most biological problems. Average alterations or trends in the estimated value of particular parameters have only limited application to a particular case, since many known and unknown substances in the body interplay; we do not know how or where to measure them precisely, and often we are not sure how the measured values should be interpreted.

The four biogenic amines that were measured in the blood during these experiments certainly must play a vital role in bodily responses to acute stress and to general anaesthesia, but their blood content varies considerably from time to time in the same animal and among the same species because of their own interactions and because they may be taken up by effector end organs almost as rapidly as they are released into the circulation. ${ }^{112,113}$ Added to these considerations is the considerable unavoidable technical error involved in their estimation. 
Therefore, unless the physiological effect of an anaesthetic is associated with a consistent and appreciable alteration in the same direction in the estimation of these substances in the blood, little stock can be placed in the changes, lest we encounter the same pitfall as those who attributed hypoxaemia to premedication with atropine ${ }^{114}$-an illogical conclusion that was easily refuted. ${ }^{115,110}$

In concluding a recent lecture on cause and effect, William Boyd said "I have probably succeeded in confusing you as much as I myself am confused, but I trust that I have made it clear that there is no more challenging problem in medical science than the intriguing but perplexing subject of causality. Finding out the 'what' in disease is not too hard, but when we come to the 'why'there's the rub. ..."117 A commentator on this lecture said in part: "In the human organism predictability falters on the brink of an abyss of variables and imponderables; cause and effect cease to bear a straight lineal relationship to each other; circular mechanisms of positive and negative feedbacks take over in the operational depths of homeostasis; purpose-the 'final' cause of Aristotle and the dark horse of science-creeps in by the back door of cybernetics; the 'chain' of causation is fast dissolving before our eyes with no other model to replace it."118 These remarks and comments certainly apply to the observations we have reported here.

Our main hope of finding the correct explanation of anaesthetic effects lies in persistence in examining and recording each physiological change that occurs in our patients while they are under the influence of an anaesthetic and, whenever possible, carrying out appropriate biochemical studies as reliable technical methods become available and applicable. Then, eventually, the clinical effects of general anaesthetics that we observe can be attributed to logical biochemical causes. Then we can apply appropriate therapeutic measures which counteract changes that are adverse for the patient.

\section{Summary and Conclusions}

Serial crossover tests were carried out on 10 to 15 large, trained, male dogs that were moderately deeply anaesthetized for 90 minutes, at two-week intervals, with thiopental, Innovar, diethyl ether cyclopropane, chloroform, trichlorethylene, fluroxene, halothane, halothane-ether azeotrope, and methoxyflurane. These tests were done under four conditions: spontaneous breathing with 50 per cent $\mathrm{N}_{2} \mathrm{O}+50$ per cent $\mathrm{O}_{2}$ unless apnoea became imminent (chloroform-usual, cyclopropane-occasional, Innovar-briefly); controlled breathing with 50 per cent $\mathrm{N}_{2} \mathrm{O}+50$ per cent $\mathrm{O}_{2}$; controlled breathing with 85 per cent $\mathrm{N}_{2} \mathrm{O}+15$ per cent $\mathrm{O}_{2}$; and controlled breathing with 50 per cent $\mathrm{N}_{2} \mathrm{O}+47.5$ per cent $\mathrm{O}_{2}+2.5$ per cent $\mathrm{CO}_{2}$. Anaesthesia was induced in all experiments with $20 \mathrm{mg} . / \mathrm{kg}$. thiopental. Cyclopropane was administered with 70 per cent oxygen in a closed-circle system with an absorber under the first two conditions only. The remaining inhalation agents were administered in a non-rebreathing system. Thiopental and Innovar were administered intravenously by drip infusion for one hour. Blood assays of histamine, serotonin, epinephrine, and norepinephrine were carried out at the beginning and end of each test along with measurements of the $\mathrm{pH}, \boldsymbol{P}_{\mathrm{ncO}}, \boldsymbol{P}_{\mathrm{nO}_{2}}$, 
haematocrit, SGOT, SGPT, lactate, pyruvate, blood water, sugar, potassium, and inorganic phosphorus. Volume of blood withdrawn for the tests was replaced with 0.9 per cent saline. During each test, mean arterial blood pressure was measured directly from the femoral artery; breathing rate and volume were monitored with a respirometer during spontaneous breathing or regulated at $\mathbf{3 5 0}$ to $400 \mathrm{ml} . / \mathrm{kg} . / \mathrm{min}$. during controlled breathing; heart rate and rhythm were monitored and recorded from E.C.G. (lead 2), and urine excretion was monitored and recorded by gravity drainage with a catheter attached to a calibrated trap bottle. All data were analyzed statistically. The following effects were noted:

1. Thiopental usually caused a rise in the catecholamines, but no hypotension or oliguria;

2. Innovar usually caused a rise in blood sugar, hypotension and oliguria; elevation of catecholamines was inconsistent;

3. Diethyl ether caused metabolic acidosis, haemoconcentration, water loss, hyperglycaemia, excess lactate, elevation of catecholamines and oliguria, but no hypotension;

4. Cyclopropane caused hypercapnoea (during spontaneous respiration) and oliguria, but no hypotension; catecholamines rose slightly;

5. Chloroform caused slight hyperglycaemia and oliguria;

6. Trichlorethylene caused oliguria and a rise in serotonin when $\mathrm{CO}_{2}$ was administered;

7. Fluroxene caused hyperglycaemia and elevated lactate and pyruvate during spontaneous breathing, a rise in the catecholamines during mild hypoxia, and oliguria;

8. Halothane, halothane-ether azeotrope, and methoxyflurane caused hypotension and oliguria, but no consistent metabolic changes.

It was evident that diethyl ether caused the most obvious metabolic disturbances, and these were usually accompanied by a rise in the catecholamines. There were virtually no consistent or appreciable changes in the histamine or serotonin assays. Theoretically, it is possible that alterations in the latter two biogenic amines might have occurred to a greater extent than the reported values indicate, since it is possible that they were released and then were taken up rapidly by the tissues or receptors of the effector organs or broken down metabolically. For that matter, catecholamines released into the blood during anaesthesia with some agents (the halogenated agents and cyclopropane) may have had the same fate, whereas with diethyl ether they remained in the bloodstream. However, it is unlikely that this occurred, for if it had, there might have been less likelihood of hypotension, at least with the more potent halogenated anaesthetics. It is important to keep in mind also that when considering the percentage changes in these biogenic amines one takes a distorted view, particularly with respect to the catecholamine values, because the assay method involves technical errors of such a magnitude that when the amount measured is near zero, or near the lower limit of detectability (as was observed with many of the control values of epinephrine), it is difficult to accept as significant those changes that appear large during an experiment.

The complex phosphorylase systems which regulate carbohydrate fat and pro- 
tein metabolism, and of which we know too little at present, the storage and functional compartments where the biogenic amines remain hidden from biochemical assay, and whose diverse actions and interactions have yet to be clearly explained, and the several cellular ions of which potassium is poorly represented in the blood serum, hold many secrets that make it virtually impossible currently to present a clear picture of mechanisms involved in the alteration in energy metabolism in response to general anaesthesia. To explain the marked difference in response of the organism to diethyl-ether anaesthesia as compared to most other general anaesthetics therefore requires far more sophisticated knowledge than we now have. We must therefore resort to guessing on the basis of the small bits of information that can with difficulty be elicited.

\section{RÉsuMÉ}

Nous avons fait une série de tests croisés sur 10 à 15 gros chiens mâles entraînés, que nous avons soumis à une anesthésie modérément profonde d'une durée de 80 minutes et, cela, à deux semaines d'intervalle, avec du thiopenthal, de l'innovar, de l'halothane, de l'halothane-éther azéotrope et du méthoxyflurane. Nous avons fait ces tests en groupant les procédés en quatre: d'abord, respiration spontanée avec 50 pour cent de protoxyde et $\mathbf{5 0}$ pour cent d'oxygène à moins que l'apnée ne devienne imminente (d'habitude on employait le chloroforme; à l'occasion, le cyclopropane; l'innovar rarement) ensuite, respiration contrôlée avec 50 pour cent de protoxyde et 50 pour cent d'oxygène puis respiration contrôlée avec 85 pour cent de protoxyde d'azote et 15 pour cent d'oxygène; enfin, respiration contrôlée avec 50 pour cent de protoxyde d'azote et 47.5 pour cent d'oxygène et 2.5 pour cent de gaz carbonique.

Dans toutes les expériences, nous avons fait l'induction avec du thiopenthal à raison de $20 \mathrm{mg} . / \mathrm{kg}$. Au cours des deux premières expériences seulement, nous avons utilisé le cyclopropane avec 70 pour cent d'oxygène en circuit fermé et avec absorption de $\mathrm{CO}_{2}$. Les autres agents par inhalation ont été administrés avec un système sans ré-inspiration. Le thiopenthal et l'innovar ont été donnés en goutte à goutte par voie endo-veineuse durant une heure. Au début et à la fin de chacune des expériences, nous avons déterminé dans le sang: l'histamine, la sérotonine, l'épinéphrine, la norépinéphrine et nous avons mesuré le $\mathrm{pH}$, la $P_{\mathrm{acO}_{2}}$, la $\boldsymbol{P}_{\mathrm{aO}_{2}}$, l'hématocrite, SGOT, SGPT, les lactates, les pyruvates, l'eau sanguine, le sucre, le potassium et le phosphore inorganique. Nous avons remplacé le volume de sang prélevé par du sérum salé à 0.9 pour cent. Au cours des tests, la pression artérielle moyenne a été mesurée directement dans l’artère fémorale; la vitesse et le volume de la respiration étaient indiqués par un respiromètre lorsque la respiration spontanée existait et ils étaient réglés de 350 à 400 $\mathrm{ml} . / \mathrm{kg} . / \mathrm{min}$. lorsque la respiration était contrôlée; la vitesse et le rythme du coeur étaient indiqués et enregistrés sur un tracé électrocardiographique en $2^{e}$ dérivation; l'excrétion d'urine était notée et mesurée par un système de drainage par gravité au moyen d'un cathéter et d'une bouteille calibrée. Toutes les données ont été analysées statistiquement. Nous avons observé les effets suivants:

D'habitude, le thiopenthal entraîne une augmentation de catécholamines, mais 
pas d'hypotension, ni d'oligurie; l'innovar produit une élévation du taux du sucre, une hypotension et une oligurie; l'élévation des catécholamines n'a pas été constantée ni prononcée; l'éther diéthylique produit une acidose métabolique, une hémoconcentration, une perte d'eau, une hyperglycémie, un excès de lactates, une élévation des catécholamines et de l'oligurie, mais pas d'hypotension; le cyclopropane cause de l'hypercapnie (durant la respiration spontanée) et de l'oligurie, mais pas d'hypotension; le taux des catécholamines s'élève légèrement; le chloroforme produit une légère hyperglycémie et de l'oligurie; le trichloréthylène cause de l'oligure et une élévation du taux de sérotonine lorsque nous administrons du $\mathrm{CO}_{2}$. Le fluroxène produit une hyperglycémie et, au cours de la respiration spontanée, une augmentation des lactates et des pyruvates et une élévation du taux des catécholamines au cours de l'hypoxie légère et de l'oligurie; l'halothane, l'halothane-éther azéotrope et le méthoxyflurane produisent de l'hypotension et de l'oligurie mais pas de changements métaboliques importants.

Evidemment, c'est l'éther diéthylique qui a causé le plus de troubles métaboliques décelables, troubles qui, d'habitude, s'accompagnent d'une élévation du taux des catécholamines. Virtuellement, nous n'avons pas observé de modifications appréciables dans le taux de l'histamine et de la sérotonine. Théoriquement, il est possible que les modifications du taux de ces deux amines biogènes aient atteint des chiffres plus élevés que ceux que nous avons obtenus, car il est possible qu'elles aient été libérées et captées rapidement par des tissus ou des récepteurs des organes affecteurs ou métabolisés. A ce sujet, les catécholamines libérées dans le sang au cours de l'anesthésie avec certains agents (les halogènes et le cyclopropane) ont pu avoir le même sort, alors qu'avec l'éther diéthylique, elles sont demeurées dans le courant sanguin. Toutefois, il est invraisemblable que cela existe ou survienne, car s'il en était ainsi, il se serait produit moins d'hypotension, du moins avec les anesthésiques halogénés les plus puissants. Il est bien important de se rappeler que lorsque l'on s'arrête au pourcentage de changement de ces amines biogènes, on peut avoir une fausse impression, particulièrement en ce qui concerne les valeurs des catécholamines, parce que la façon de mesurer peut avoir des facteurs d'erreur d'une telle amplitude que, lorsque la quantité mesurée est près de zéro, ou près de la limite inférieure dépistable (comme nous l'avons observé avec plusieurs des contrôles des valeurs de l'épinéphrine), il devient difficile d'accepter comme changements importants ce qui s'est avéré élevé au cours des expériences.

Les systèmes complexes de phosphorylase qui règlent le métabolisme des hydrates de carbone, des graisses et des protéines, dont nous connaissons trop peu actuellement l'emmagasinage et les sections fonctionnelles où les amines biogènes se cachent et se soustraient aux analyses biochimiques et dont les actions diverses et les interactions demeurent encore à expliquer, les nombreux ions cellulaires dont le potassium qui est si peu élevé dans le sérum sanguin, tout cela renferme encore plusieurs secrets qui nous rendent pratiquement incapables de présenter un tableau précis des mécanismes impliqués dans les modifications du métabolisme énergétique en réponse à l'anesthésie générale. Pour expliquer la différence marquée dans la réponse de l'organisme à l'anesthésie à l'éther diéthylique et d l'anesthésie avec la plupart des autres agents anesthésiques généraux, il faudrait 
beaucoup plus de connaissances que nous n'en avons. En conséquence, il nous faut recourir à l’à peu près basé sur des parcelles de renseignements que l'on ne peut vérifier qu'avec difficulté.

\section{ACKNOWLEDGMENTS}

The authors are grateful to Prof. John B. Henry, M.D., Prof. Min H. Cho, M.D., Ph.D., Benjamin Africa, M.D., George Mann, R.T., Christina Bisset, R.N., Enid Racz, R.T., Phyllis DiRaddo, R.T., Archie Canton, R.T., and Robert Gelder, M.A, for technical advice and assistance.

\section{REFERENCES}

1. WeIL-Malferre, H. Concentration of Adrenalin in Human Plasma and Its Relationship to Mental Activity. J. Ment. Sc. 101: 733 (1955).

2. Runckel, M. \& Soromon, H. C. Chemical Theories of Psychosis. J. Clin. Exp. Psychopathol. 13: 323 (1957).

3. Stern, P.; Hukovic, S.; Madjerex, $Z_{\text {; }}$ \& Karabaic, S. The Histamine Level of the Blood of Schizophrenic Subjects. Arch. Int. Pharmacodyn. 109: 294 (1957).

4. LeE, P. K. Y.; Cho, M. H.; \& Dobkn, A. B. Effect of Catecholamine Precursors and Phenylalanines on Spontaneous Activity and on the Response to Methohexital Anaesthesia. Canad. Anaesth. Soc. J. 12: 137 (1965).

5. Moore, F. D. Endocrine Changes After Anesthesia, Surgery, and Unanesthetized Trauma in Man. Recent Prog. Hormone Res. 13: 511 (1957).

6. Price, H. L.; Linde, H. W.; Jones, R. E.; Black, G. W.; \& Pruce, M. L.. Sympathoadrenal Responses to General Anesthesia in Man and Their Relation to Hemodynamics. Anesthesiology. 20: 563 (1959).

7. Bunker, J. P. Neuroendocrine and Other Effects on Carbohydrate Metabolism during Anesthesia. Anesthesiology. 24: 515 (1963).

8. Way, E. L. \& Sutrerruand, V. C. Pharmacologically Active Brain Substances and Their Relation to Endocrine Effects. Anesthesiology. 24: 543 (1963).

9. BAEz, S. \& Orkin, L. R. Effects of Anesthetics on the Response of the Microcirculation to Circulating Humors. Anesthesiology. 24: 568 (1963).

10. Severinghaus, J. W. \& Bradley, A. F. Electrode for Blood $P_{\mathrm{O}_{2}}$ and $P_{\mathrm{OO} 2}$ Determination. J. Appl. Physiol. 13: 515 (1958).

11. Comroe, J. H., Jr. et al. The Lung. 2nd ed., Clinical Physiology and Pulmonary Function Tests. Chicago: Yearbook Medical Publishers (1962), p. 346.

12. Nater.son, S. Routine Use of Ultramicromethods in Clinical Laboratory. Am. J. Clin. Pathol. 21: 1153 (1951).

13. Büchen, T. Pyruvate in Methods of Enzymatic Analysis. H. U. Bergmeyer, ed., Academic Press (1963), pp. 253-259.

14. Horonst, H. J. L- $(+)$-Lactate, Determination with Lactic Dehydrogenase and D.P.N. in Methods of Enzymatic Analysis. H. U. Bergmeyer, ed., Academic Press (1963), pp. 266-270.

15. Rertman, S. \& Frankel, S. A Colorimetric Method for Determination of Serum Glutamic Oxalacetic and Glutamic Pyruvic Transaminases. Am. J. Clin. Pathol. 28: 56 (1957).

16. Hoffman, W. S. A Rapid Photoelectric Method for the Determination of Glucose in Blood and Urine. J. Biol. Chem. 120: 51 (1937).

17. Fiske, C. H. \& Subbarow, Y. The Colorimetric Determination of Phosphorus J. Biol. Chem, 66: 375 ( 1925 ).

18. Weissbach, H.; Wanlzes, T. P.; \& Udenfrnend, S. A Simplified Method for Measuring Serotonin in Tissues: Simultaneous Assay of Both Serotonin and Histamine. J. Biol. Chem. 230: 865 (1958).

19. Crawrond, N. \& RuDd, B. T. A Spectrophotofluorometric Method for the Determination of Serotonin (5-Hydroxytryptamine) in Plasma. Clinica Chemica Acta. 7: 114 (1962).

20. Noan, J. W. \& Brand, A. Simple Micromethod for Measuring Histamine in Human Plasma. J. Lab. \& Clin. Med. 62: 506 (1963). 
21. Cohen, G. \& Goldonmerrc, M. The Simultaneous Fluorometric Determination of Adrenalin and Noradrenalin in Plasma. J. Neurochem. 2: 58 (1957).

22. Price, H. L. \& Price, M. L. The Chemical Estimation of Epinephrine and Norepineephrine in Human and Canine Plasma: Critique of Trihydroxylindole Method. J. Lab. \& Clin. Med. 50: 769 (1957).

23. McGowan, G. K. \& Walters, G. Value of Measuring Central Venous Pressure in Shock. Brit. J. Surg. 50: 821 (1963).

24. Leading Article: Central Venous Pressure in Oligaemic Shock. Lancet. i: 1143 (1964).

25. Dobrin, A. B. The Effects of Anaesthetic Agents on the Cardiovascular System: A Review. Canad. Anaesth. Soc. J. 7: 317 (1960).

26. Smitr, H. W.; Rovenstine, E. A.; Goldrnng, W.; Chasis, H.; \& Ranges, H. A. The Effects of Spinal Anesthesia on the Circulation in Normal Unoperated Man with Respect to the Autonomy of the Arterioles and Especially Those of the Renal Circulation. J. Clin. Invest. 18: 319 (1939).

27. Moran, W. H.; Mutenberger, F. W.; Shuayb, W. A.; \& Zmmerman, B. The Relationship of Antidiuretic Hormone Secretion to Surgical Stress. Surgery. 56: 99 (1964).

28. Papper, S. \& Papper, E. M. The Effects of Preanesthetic Medication, Anesthetic, and Postoperative Drugs on Renal Function. Clin. Pharmacol. \& Therap. 5: 205 (1964).

29. Doskn, A. B. Regulation of Controlled Respiration: Recent Concepts Important to the Anaesthetist. Brit. J. Anaesth. 30: 282 (1958).

30. Tepperman, J. Metabolic and Endocrine Physiology. Chicago: Yearbook Medical Publishers (1962).

31. Gaddum, SIR JoHn. Pharmacology of the Central Nervous System. Brit. M. Bull. 21: 1 (1965).

32. GreEN, J. P. Histamine and the Nervous System. Fed. Proc. 23: 1095 (1964).

33. Euxrort, K. A. C. Gamma Aminobutyric Acid and Other Inhibitory Substances. Brit. M. Bull. 21: 70 (1965).

34. Trendelenderk, U. Supersensitivity and Subsensitivity to Sympathomimetic Amines. Pharmacol. Rev. 15: 225 (1963).

35. Bendixen, H. H.; Oscood, P. F.; Hall, K. V.; \& Laver, M. B. Dose-Dependent Differences in Catecholamine Action on Heart and Periphery. J. Pharmacol. \& Exper. Therap. 145: 299 (1964).

36. HunTER, F. E. \& Lowny, O. H. The Effects of Drugs on Enzyme Systems. Pharmacol. Rev. 8: 89 (1956).

37. Quastel, J. H. Effects of Drugs on Metabolism of the Brain in Vitro. Brit. M. Bull. 21: 49 (1965).

38. Woolley, D. W. The Biochemical Bases of Psychoses. New York: J. Wiley (1962).

39. Bock, K. D. \& MEIER, M. The Effect of Atropine on Cardiovascular Reactions Elicited by Catecholamines, Angiotensin, Histamine, Serotonin, and Acetylcholine in the Conscious Dog. Arch. Int. Pharmacodyn. 142: 444 (1963).

40. VanBrunt, E. E. \& Ganong, W. F. The Effects of Preanesthetic Medication, Anesthesia and Hypothermia on the Endocrine Response to Injury. Anesthesiology. 24: 500 (1963).

41. Westcate, H. D. \& VanBercen, F. H. Changes in Histamine Blood Levels Following d-Tubocurarine Administration. Canad. Anaesth. Soc. J. 9: 497 (1962).

42. Murphy, P. Histamine in Anaesthesia: A Short Survey. Brit. J. Anaesth. 34: 397 (1962).

43. Thompson, W. L. \& Walton, R. P. Elevation of Plasma Histamine Levels in the Dog Following Administration of Muscle Relaxants, Opiates, and Macromolecular Polymers. J. Pharmacol. \& Exper. Therap. 143: 131 (1964).

44. Aviado, D. M. Histamine in the Causation of Shock. Pharmacologist. 7: 31 (1965).

45. SpIEs, T. D. \& STONE, R. E. Effect of Serotonin on Blood Pressure and Lack of Effect of Antimetabolite. J.A.M.A. 150: 1599 (1952).

46. Comrox, J. H. Direct and Reflex Cardiopulmonary Effects of Serotonin (5-OH-Tryptamine): Their Relation to Pulmonary Embolism. Am. J. Physiol. 171: 715 (1952).

47. PAGE, I. H. Serotonin (5-Hydroxytryptamine): The Last Four Years. Physiol. Rev. 38: 277 (1958).

48. Lewis, G. P., ed. 5-Hydroxytryptamine. New York: Pergamon Press (1958).

49. ANDERSon, E. G. \& Bonnycastle, D. D. A Study of the Central Depressant Action of Pentobarbital, Phenobarbital and Diethyl Ether in Relationship to Increases in Brain 5-Hydroxytryptamine. J. Pharmacol. \& Exper. Therap. 130: 138 (1960). 
50. Aston, R.; Dan, K.; \& Greifenstenn, F. Effect of Anesthesia Upon Venous 5-Hydroxytryptamine Levels. Anesth. \& Analg. 42: 624 (1963).

51. Shore, P. A. Release of Serotonin and Catecholamines by Drugs. Pharmacol. Rev. 14: 531 (1962).

52. von Euler, U. S. Quantitation of Stress by Catecholomine Analysis. Clin. Pharmacol. Therap. 5: 398 (1964).

53. Price, H. L. Circulatory Adrenaline and Noradrenaline During Diethyl Ether Anesthesia in Man. Clin. Sc. 16: 377 (1957).

54. Richardson, J. A.; Woods, E. F.; \& Richandson, A. K. Plasma Concentration of Epinephrine and Norepinephrine During Anesthesia. J. Pharmacol. \& Exper. Therap. 119: 378 (1957).

55. MIIIER, R. A. \& Morris, M. E. Sympatho-adrenal Responses During General Anaesthesia in the Dog and Man. Canad. Anaesth. Soc. J. 8: 356 (1961).

56. KäGr, J. Veränderungen der Adrenalin- und Noradrenalinkonzentrationen im menschlichen Blutplasma während der Athernarkose. Arch. Exper. Path. u. Pharmakol. 230: 479 (1957).

57. Hamelaerg, W.; Sprouse, J. H.; Mahafrex, J. E.; \& Righardoson, J. A. Catecholamine Levels during Light and Deep Anesthesia. Anesthesiology. 21: 297 (1960).

58. MrLler, R. A. \& Morris, M. E. Induced Sympathetic Stimulation during Halothane Anaesthesia. Canad. Anaesth. Soc. J. 7: 423 (1960).

59. MILLER, R. A. \& MIILER, M. E. A Study of Methoxyflurane Anaesthesia. Canad. Anaesth. Soc. J. 8: 210 (1961).

60. SeEurg, A. Uber Atherglykosurie und ihre Beeinflussung durch intravenose Sauerstoffinfusionen. Arch. Exper. Path. u. Pharmakol. 52: 481 (1905).

61. Foldes, F. F.; Murphy, A. J.; \& WIrson, B. C. The Effect of Various Anesthetic Agents on Inorganic Serum Phosphorus Levels. J. Pharmacol. \& Exper. Therap. 100: $14(1950)$.

62. Henneman, D. H. \& Bunker, J. P. Effects of General Anesthesia on Peripheral Blood Levels of Carbohydrate and Fat Metabolites and Serum Inorganic Phosphorus. J. Pharmacol. \& Exper. Therap. 133: 253 (1961).

63. Henneman, D. H. \& Vandam, L. D. Effect of Epinephrine, Insulin, and Tolbutamide on Carbohydrate Metabolism during Ether Anesthesia. Clin. Pharmacol. Therap. I: 694 (1960).

64. Giebisch, G.; Benger, L.; \& Pitts, R. F. Extrarenal Response to Acute Acid-Base Disturbances of Respiratory Origin. J. Clin. Invest. 34: 231 (1955).

65. StEWARD, J. D. \& Rourke, G. M. Changes in Blood and Interstitial Fluid Resulting from Surgical Operation and Ether Anesthesia. J. Clin. Invest. 17: 413 (1938).

66. Robins, B. H. \& Pratt, H. A. Ether Anesthesia: Changes in the Serum Potassium Content during and Following Anesthesia. J. Pharmacol. \& Exper. Therap. 56: 205 (1936).

67. Shimes, T.; Wirriams, J.; \& Brown, F. Acute Change in Extracellular Fluids Associated with Major Surgical Procedures. Ann. Surg. 154: 803 (1961).

68. DoRkIN, A. B.; HARLAND, J. H.; \& FEDORUX, S. Chloroform and Halothane in a Precision System. Comparison of Some Cardiovascular, Respiratory, and Metabolic Effects in Dogs. Brit. J. Anaesth. 33: 239 (1961).

69. Dobxin, A. B. \& Fedonuk, S. Comparison of the Cardiovascular, Respiratory, and Metabolic Effects of Methoxyflurane and Halothane in Dogs. Anesthesiology. 22: 355 (1961).

70. Domkin, A. B.; Lee, P. K. Y.; Byles, P. H.; \& Israed, J. S. Neuroleptanalgesics: A Comparison of the Cardiovascular, Respiratory and Metabolic Effects of Innovan and Thiopentone Plus Methotrimeprazine. Brit. J. Anaesth. 35: 694 (1963).

71. Donxin, A. B.; Israex, J. S.; \& ByLrs, P. H. Innovan- $\mathrm{N}_{2} \mathrm{O}$ Anaesthesia in Normal Men: Effect on Respiration Circulatory Dynamics, Liver Function, Metabolic Functions, Acid-Base Balance, and Psychic Responses. Canad. Anaesth. Soc. J. 11: 41 (1964).

72. Brown, E. B., JR. Hole of Hyperkalemia in Production of Ventricular Fibrillation Following Hypercapnia. Proc. Soc. Exper. Biol, \& Med. 90: 319 (1955).

73. LADE, R. I. \& BROWN, E. B., JB. Movement of Potassium Between Muscle and Blood in Response to Respiratory Acidosis. Am. J. Physiol. 204: 761 (1963).

74. Huckarez, W. E. Relationship of Pyruvate and Lactate during Anaerobic Metabolism: I. Effects of Infusion of Pyruvate or Glucose and of Hyperventilation. J. Clin. Invest. 37: 244 (1958). 
75. -_- Relationship of Pyruvate and Lactate during Anaerobic Metabolism: II. Exercise and Formation of $\mathrm{O}_{2}$-Debt. J. Clin. Invest. 37: 255 (1958).

76. _- Relationship of Pyruvate and Lactate during Anaerobic Metabolism: III. Effect of Breathing Low Oxygen Gases. J. Clin. Invest. 37: 264 (1958).

77. Broder, G. \& Wen, M. H. Excess Lactate: Index of Reversibility of Shock in Human Patients. Science. 143: 1457 (1964).

78. Olson, R. E. "Excess Lactate" and Anaerobiosis. Ann. Int. Med. 59: 960 (1963),

79. Boxer, G. E. \& Devrnw, T. M. Pathways of Intracellullar Hydrogen Transport. Science. 134: 1495 (1961).

80. Greene, N. M. Lactate, Pyruvate, and Excess Lactate Production in Anesthetized Man. Anesthesiology. 22: 404 (1961).

81. GreEnE, N. M. Inhalation Anesthetics and Carbohydrate Metabolism. Baltimore: Williams \& Wilkins (1963).

82. Lowenstein, E.; Clark, J. D.; \& Vinlareal, Y. Excess Lactate Production during Halothane Anesthesia in Man. J.A.M.A. 190: 1110 (1964).

83. Marx, G. F. \& Greene, N. M. Maternal Lactate, Pyruvate, and Excess Lactate Production during Labor and Delivery. Am. J. Obs. \& Gyn. 90: 786 (1964).

84. Thendelenburg, U. G. The Norepinephrine Stores and Their Functional Compartments. Anesthesiology. 25: 259 (1964).

85. Haugaard, N. \& Hess, M. E. Actions of Autonomic Drugs on Phosphorylase Activity and Function. Pharmacol. Rev. 17: 27 (1965).

86. SuUtarinen, T. H.; NÄrvänen, S.; \& Ahola, T. Effect of Fluothane on Some Blood Metabolites during Thoracotomy in Children With Congenital Heart Disease. Acta Anaesth. Scandinav. 8: 131 (Suppl. XV).

87. MaAlisster, F. F. Effect of Ether Anesthesia on Volume of Plasma and Extracellular Fluid. Am. J. Physiol. 124: 391 (1938).

88. McAlruster, F. F. \& Roor, W. S. The Neurogenic Control of the Circulation of Dogs under Ether Anesthesia. Anesthesiology. 3: 491 (1942).

89. Robertson, J. D. \& Frazen, S. C. Biochemical Disturbances Associated with Anaesthesia. Brit. M. Bull. 14: 8 (1958).

90. Crawford, E. J. \& Gaudino, M. Changes in Extracellular Fluid Volume, Renal Function, and Electrolyte Excretion Induced by Intravenous Saline Solution and by Short Periods of Anesthesia. Anesthesiology. 13: 374 (1952).

91. HAYEs, M. A. \& ColikR, F. A. The neuroendocrine Control of Water and Electrolyte Excretion during Surgical Anesthesia. Surg. Gynec. \& Obst. 96: 674 (1953).

92. Dudley, H. F.; Bolnnc, E. A.; LEQuesne, L. P.; \& Moore, F. D. Effects of Anesthesia, Surgery, and Posterior Pituitary Antidiuretic Hormone on Water Metabolism in Man. Ann. Surg. 140: 354 (1954).

93. Aprahaminn, H. A.; Vanderveen, J. L.; Bunger, J. P.; Munphy, A. J.; \& Crawrord, J. D. The Influence of General Anesthetics on Water and Solute Excretion in Man. Ann. Surg. 150: 122 (1959).

94. Barcroft, J. \& Rothschild, P. Effect of Certain Anaesthetics on Volume of Exteriorized Spleen. Arch. internat. pharmacodyn. 38: 569 (1930).

95. Hausner, E.; Essex, H. E.; \& MaNN, F. C. Roentgenologic Observations of Spleen of Dog under Ether, Sodium Amytal, Pentobarbital Sodium, and Pentothal Sodium Anesthesia. Am. J. Physiol. 121: 387 (1938).

96. Goldenderc, I. S.; Hayes, M. A.; \& GreEne, N. M. Endocrine Responses during Operative Procedures. Ann. Surg. 150: 196 (1959).

97. Bounne, W. \& Barbour, H. G. Heat Regulation and Water Exchange: Influence of Ether in Dogs. Am. J. Physiol. 67: 399 ( 1924 ).

98. Barmour, H. G. Water Exchanges Due to Anesthetic Drugs. Anesthesiology. 1: 121 (1940).

99. Cournand, A.; Rmey, R. L.; Bradley, S. E.; Breed, E. S.; Noble, R. P.; Lanson, H. D.; Gregerson, M. I.; \& RichaRds, D. W. Studies of the Circulation in Clinical Shock. Surgery. 13: 964 (1943).

100. Egert, R. J. \& Stead, E. A. Demonstration That the Cell Plasma Ratio of Blood Contained in Minute Vessels is Lower Than That of Venous Blood. J. Clin. Invest. 20: 317 (1941).

101. Searles, P. W. The Effect of Certain Anesthetics on the Blood. J.A.M.A. 113: 908 (1939).

102. SJostrand, T. Volume and Distribution of Blood and Their Significance in Regulating the Circulation. Physiol. Rev. 33: 202 (1953). 
103. Freeman, N. E. Decrease in Blood Volume after Prolonged Hyperactivity of the Sympathetic Nervous System. Am. J. Physiol. 103: 185 (1933).

104. Schmutzen, K. J.; RASChKE, E.; \& MaLONEY, J. V. Intravenous l-Norepinephrine as a Case of Reduced Plasma Volume. Surgery. 50: 452 (1961).

105. DoBkin, A. B.; LEE, P. K. Y.; \& BYLES, P. H. Neuroleptanalgesics: 2. Laboratory Evaluation of Combination of Analgesics and Neuroleptics with Nitrous Oxide. Canad. Anaes. Soc. J. 12: 39 (1965).

106. Dobkin, A. B;; ByLes, P. H.; \& CHо, M. H. Neuroleptanalgesics: 3. Effect of InnovarNitrous-Oxide Anaesthesia on Blood Levels of Histamine, Serotonin, Epinephrine, and Norepinephrine, and on Urine Excretion. Canad. Anaesth. Soc. J. 12: 349 (1965).

107. MUELLER, C. B. The Mechanism of Acute Renal Failure after Injury and Transfusion Reaction and Its Prevention by Solute Diuresis. Surg. Clin. N.A. 45: 499 (1965).

108. Habm, D. V.; Papper, E. M.; Fitzpatrick, H. F.; Lowrance, P.; Smythe, C. McC.; \& BradLey, S. E. The Renal and Hepatic Blood Flow, Glomerular Filtration Rate, and Urinary Output of Electrolytes during Cyclopropane, Ether, and Thiopental Anesthesia Operation and the Immediate Postoperative Period. Surgery. 30: 241 (1951).

109. Miles, B. E. \& DeWardener, H. E. Renal Vasoconstriction Produced by Ether and Cyclopropane Anaesthesia. J. Physiol. 118: 140 (1952).

110. Hopins, R. W.; SabGa, G.; Bernardo, P.; Penn, I.; \& Stmeone, F. A. Significance of Post-Traumatic and Postoperative Oliguria. Arch. Surg. 87: 320 (1963).

111. Bacmanan, L. Antidiuretic Effects of Anesthetic Agents. Anesthesiology. 16: 939 (1955).

112. Grees, J. P. Binding of Some Biogenic Amines in Tissues. Advances in Pharmacology, vol. 1, S. Garattini and P. A. Shore, ed., New York: Academic Press (1962), p. 162.

113. MARLEX, E. The Adrenergic System and Sympathomimetic Amines. Advances in Pharmacology, vol. 3 ( 1964), p. 168.

114. Tomin, P. J.; Conway, C. M.; \& PaYne, J. P. Hypoxaemia Due to Atropine. Lancet. i: 14 (1964).

115. TaYLOR, S. H.; Scott, D. B.; \& DonaLd, K. W. Respiratory Effects of General Anaesthesia. Lancet. $i: 841$ (1964).

116. Gardiner, A. S. J. \& Paimer, K. N. V. Effect of Premedication and General Anaesthesia on Arterial Blood Gases. Brit. Med. J. 2: 1433 (1964).

117. Boxp, Wrumam. Cause and Effect: The Fifth Alexander Gibson Memorial Lecture. Canad. M.A.J. 92: 868 (1965).

118. Editorial. Effect and Cause. Canad. M.A.J. 92: 882 (1965). 